\title{
Fullerene mediates proliferation and cardiomyogenic differentiation of adipose-derived stem cells via modulation of MAPK pathway and cardiac protein
} expression

\author{
This article was published in the following Dove Press journal: \\ International Journal of Nanomedicine \\ 18 January 2016 \\ Number of times this article has been viewed
}

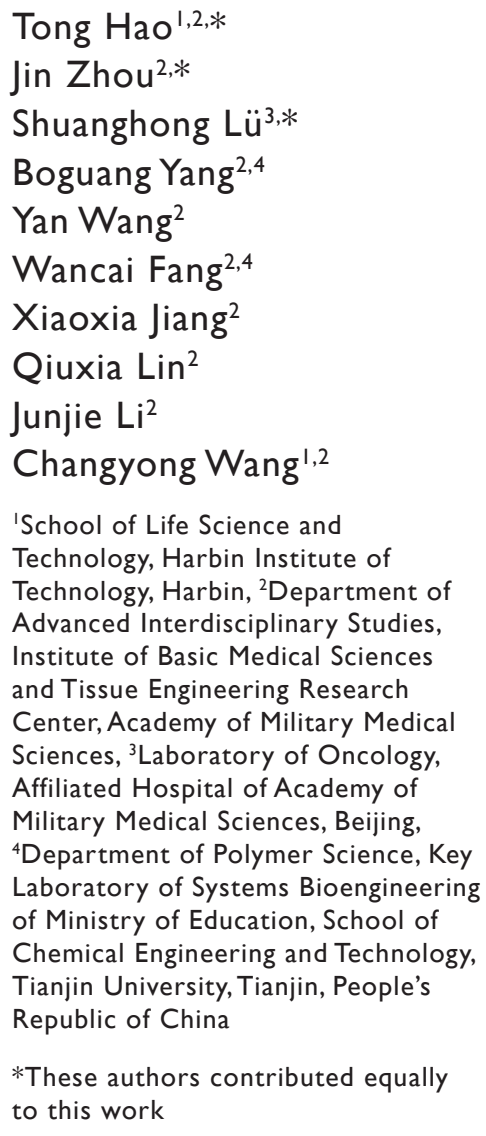

Correspondence: Changyong Wang School of Life Science and Technology, Harbin Institute of Technology, Harbin I5000I, People's Republic of China Email wangchy@bmi.ac.cn

Junjie Li

Department of Advanced Interdisciplinary Studies, Institute of Basic Medical

Sciences and Tissue Engineering Research

Center, Academy of Military Medical

Sciences, 27 Taiping Rd, Beijing I00850,

People's Republic of China

Email li41308@aliyun.com

\begin{abstract}
Zero-dimensional fullerenes can modulate the biological behavior of a variety of cell lines. However, the effects and molecular mechanisms of proliferation and cardiomyogenic differentiation in brown adipose-derived stem cells (BADSCs) are still unclear. In this study, we report the initial biological effects of fullerene- $\mathrm{C}_{60}$ on BADSCs at different concentrations. Results suggest that fullerene- $\mathrm{C}_{60}$ has no cytotoxic effects on BADSCs even at a concentration of $100 \mu \mathrm{g} / \mathrm{mL}$. Fullerene- $\mathrm{C}_{60}$ improves the MAPK expression level and stem cell survival, proliferation, and cardiomyogenesis. Further, we found that the fullerene$\mathrm{C}_{60}$ modulates cardiomyogenic differentiation. Fullerene- $\mathrm{C}_{60}$ improves the expression of cardiomyocyte-specific proteins (cTnT and $\alpha$-sarcomeric actinin). At elevated concentration, fullerene- $\mathrm{C}_{60}$ reduces the incidence of diminished spontaneous cardiac differentiation of BADSCs with time. At the genetic level, fullerene- $\mathrm{C}_{60}(5 \mu \mathrm{g} / \mathrm{mL})$ also improves the expression of cTnT. In addition, fullerene- $\mathrm{C}_{60}$ promotes the formation of gap junction among cells. These findings have important implications for clinical application of fullerenes in the treatment of myocardial infarction.
\end{abstract}

Keywords: $\mathrm{C}_{60}$, BADSCs, molecular mechanisms, myocardium

\section{Introduction}

Nanotechnology, the use of nanomaterials $<100 \mathrm{~nm}$ in size, is an emerging area of regenerative medicine encompassing biomarkers discovery, cell therapy, and tissue engineering. ${ }^{1-3}$ Nanomaterials easily enter cells by direct penetration or receptormediated endocytosis and are translocated into different organelles, to modulate the biological behaviors of cell. ${ }^{4}$ Recently, carbon nanomaterials such as zero-dimensional (0D) fullerenes, one-dimensional (1D) carbon nanotubes (CNTs), and two-dimensional (2D) graphene have been used to recreate the specialized local microenvironment for optimal cell growth and differentiation to specific cell types. ${ }^{5}$ Fullerene- $\mathrm{C}_{60}$, first reported by Kroto et al in $1985,{ }^{6}$ is a remarkably stable cage-like molecule measuring $\sim 0.7 \mathrm{~nm}$ in diameter, facilitating passive diffusion into cells and nuclei. In addition to its structural significance, fullerene- $\mathrm{C}_{60}$ is available as a pure compound, while graphene and CNT are poorly defined material structures, ${ }^{7}$ resembling clathrincoated vesicles in cells. ${ }^{8}$ Further, the fullerene- $\mathrm{C}_{60}$ is biocompatible and does not induce cellular apoptosis/death ${ }^{9}$ or elicit reactive-inflammatory response compared with graphite and single-walled CNT. ${ }^{10}$ In addition, fullerene- $\mathrm{C}_{60}$ can bind the hydrophobic drug, protein and/or hydrophobic regions of DNA due to the highly hydrophobic nature of the spherical structure and further modulate the cellular physiology. Recently, studies 
suggest that fullerene- $\mathrm{C}_{60}$ easily enter cells and the nucleus in both normal and carcinoma cells, to further modulate their biological behavior. Nishimura et $\mathrm{al}^{11}$ investigated the biological role of fullerene- $\mathrm{C}_{60}$ using mouse embryonic stem cells, and found that the uptake of fullerene- $\mathrm{C}_{60}$ occurs in a concentration-dependent fashion from 2 to $20 \mu \mathrm{g} / \mathrm{mL}$. The growth rate of cells was not influenced when the concentration of fullerene- $\mathrm{C}_{60}$ was $<15 \mu \mathrm{g} / \mathrm{mL}$.

Mesenchymal stem cells (MSCs)-based regenerative medicine is a promising strategy for the treatment of myocardial infarction (MI). ${ }^{12-15}$ Therapeutic efficacy is limited by the low proliferative rate and cardiac differentiation efficiency in vivo. ${ }^{16}$ Previous studies suggested that brown adipose-derived stem cells (BADSCs) are an ideal source for the treatment of MI due to their high cardiomyogenic differentiation potential. MAPKs, including ERK, p38, and c-JNK, play essential roles in the regulation of BADSCs' biological effects. The ERK MAPK plays a cytoprotective role, whereas the JNK and p38 MAPK cascades mediate pro-apoptotic or cardiomyogenic differentiation. ${ }^{17,18}$

Carbon nanomaterials modulate the biological behavior of MSCs by regulating the expression of MAPK due to their superior strength and electrical conductivity. Park et al ${ }^{19}$ found that $2 \mathrm{D}$ graphene regulates the cardiomyogenic differentiation of MSCs by enhancing the expression of extracellular matrix proteins and cellular FAK-Src-ERK/ JNK signaling molecules. In addition, 1D CNT-based nanomaterials induce MSCs differentiation toward cardiac progenitor cells in vitro and in vivo. ${ }^{20,21}$ Our previous study showed that the CNTs can accelerate gap junction formation remarkably via activation of the $\beta 1$-integrinmediated FAK/ERK/GATA4 pathway. ${ }^{22}$ Yang et $\mathrm{al}^{23}$ found that the 0D fullerol enhances the osteogenesis of human adipose-derived stem cells. Despite these exciting findings, relatively little is known about the molecular mechanism of fullerene- $\mathrm{C}_{60}$ in proliferation and cardiomyogenic differentiation of MSCs.

In the present study, we investigated the effects of $0 \mathrm{D}$ fullerene- $\mathrm{C}_{60}$ on the biological behavior of BADSCs, including survival, apoptosis, proliferation, and cardiomyogenic differentiation. To this end, we focused on the regulation of ERK1/2 MAPK and p38 MAPK signal transduction pathways of BADSCs under different levels of fullerene- $\mathrm{C}_{60}$. The cardiomyogenic differentiation capacity of BADSCs in the presence of fullerene- $\mathrm{C}_{60}$ was also evaluated. The transcriptional and translational expression of $\mathrm{cTnT} / \alpha-$ sarcomeric actinin in BADSCs was also investigated along with the effects of fullerene- $\mathrm{C}_{60}$ on the gap junction protein Cx-43.

\section{Materials and methods Isolation, cultivation, and characterization of rat BADSCs}

BADSCs were acquired from interscapular adipose tissue of $60-80 \mathrm{~g}$ Sprague Dawley rats as previously described. ${ }^{24,25}$ Animal experimental procedures were conducted according to the Guide for the Care and Use of Laboratory Animals and approved by the Institutional Animal Care and Use Committee of the Chinese Academy of Military Medical Science (Beijing, People's Republic of China). Briefly, isolated brown adipose tissues were washed extensively using phosphate-buffered saline (PBS; pH 7.4) to remove contaminating debris and red blood cells. These tissues were minced and digested with $0.1 \%$ collagenase IV (Sigma-Aldrich Co., St Louis, MO, USA), $0.1 \%$ dispase II (Hoffman-La Roche Ltd., Basel, Switzerland), and $0.05 \%$ trypsin (Sigma-Aldrich Co.) in serum-free medium at $37^{\circ} \mathrm{C}$ for 40 minutes. The enzymes were inactivated by Minimum Essential Medium Eagle Alpha Modification $/ 10 \%$ fetal bovine serum (Thermo Fisher Scientific, Waltham, MA, USA), and the samples were filtered to remove debris. Finally, the BADSCs were collected by centrifugation, resuspended in Minimum Essential Medium Eagle Alpha Modification $/ 15 \%$ fetal bovine serum, and cultured at $37^{\circ} \mathrm{C}$ and $5 \% \mathrm{CO}_{2}$. The medium was replaced every other day. Flow cytometry (BD, Franklin Lakes, NJ, USA) was used to analyze and confirm the immunophenotype of BADSCs (Figure S1). In addition, the osteogenic and adipogenic differentiation activities were measured by Von Kossa staining (Figure S2) on day 14 and Oil Red O staining on day 7 (Figure S3), respectively.

\section{Fullerene treatment}

The freshly isolated BADSCs were seeded in plates at an appropriate density. At appropriate level of confluency after $\sim 72$ hours, cells were washed with PBS. Fresh complete culture medium containing fullerene (Timesnano Co., Chengdu, People's Republic of China) at different concentrations $(0,5,25,50$, and $100 \mu \mathrm{g} / \mathrm{mL})$ was added. The medium was replaced every other day.

\section{MTT assay}

We added $200 \mu \mathrm{L}$ of culture medium containing $5 \times 10^{3}$ BADSCs into 96-well tissue culture plates and incubated at $37^{\circ} \mathrm{C}$ and $5 \% \mathrm{CO}_{2}$ for 24 hours. The medium was replaced by the culture medium containing fullerene at different concentration. Cells without fullerene treatment were used as control. On days 1, 3, 5, and 7, $20 \mu \mathrm{L}$ of 3-(4,5-dimethylthiazol-2yl)-2,5-diphenyltetrazolium bromide (MTT) $(5.0 \mathrm{mg} / \mathrm{mL}$, Sigma-Aldrich Co.) was added to each well and incubated for 4 hours at $37^{\circ} \mathrm{C}$. Then, the supernatant was removed, and 
$150 \mu \mathrm{L}$ of DMSO was added, and the absorbance at $490 \mathrm{~nm}$ was recorded on a microplate spectrophotometer (Molecular Devices, Sunnyvale, CA, USA).

\section{Acridine orange/propidium iodide staining}

The survival of BADSCs after fullerene treatment was investigated with acridine orange (AO) and propidium iodide (PI) staining. On days $1,3,5$, and 7 of culture in the fullerene suspensions, BADSCs were stained by $\mathrm{AO}(0.67 \mu \mathrm{M})$ and PI $(75 \mu \mathrm{M})$ for 10 minutes, respectively, according to the manufacturer's instructions. The cellular morphology was visualized under fluorescence microscope (Leica, Wetzlar, Germany).

\section{Flow cytometry assay}

The effects of fullerenes on apoptosis of BADSCs were assessed by Annexin V-fluorescein isothiocyanate (V-FITC; Baosai, Beijing, People's Republic of China) and PI staining followed by analysis with flow cytometry. On day 3 after treatment with fullerenes, all the cells were collected and washed twice using cold PBS. Into each cell suspension, $10 \mu \mathrm{L}$ of Annexin V-FITC was added and incubated for 15 minutes in the dark, followed by addition of $5 \mu \mathrm{L}$ of PI. The proportion of apoptotic-positive cells was analyzed using fluorescenceactivated cell sorter (FACScan, BD) immediately.

\section{Bromodeoxyuridine staining}

Cells $\left(8 \times 10^{4}\right)$ were seeded in 24 -well plates. On days 1 , 3,5 , and 7 after fullerenes treatment, cells were incubated with bromodeoxyuridine (BrdU) for 1 hour and stained with anti-BrdU antibody (Sigma-Aldrich Co.) according to the manufacturer's instructions. After washing with PBS containing 1\% Triton X-100 three times, the cells were treated with anti-rabbit $\mathrm{Cy} 3$ fluorescent-conjugated secondary antibodies at room temperature for 90 minutes. Cell nuclei were visualized with 4',6-diamidino-2-phenylindole (DAPI). Finally, the cells were observed under fluorescence microscope (Leica). BrdU-positive $\left(\mathrm{BrdU}^{+}\right)$cells were counted from ten randomly selected fields of three independent samples. Proliferation activity of BADSCs was defined as the percentage of $\mathrm{BrdU}^{+}$ cells relative to the total number of DAPI-positive cells. The results are presented as the mean \pm standard deviation (SD).

\section{Transmission electron microscopic observation}

The ultrastructural details and internalization of BADSCs in the presence of fullerene were observed using transmission electron microscopy (TEM). Briefly, BADSCs were incubated with fullerene $(50 \mu \mathrm{g} / \mathrm{mL})$ for 1 day. Cells were washed with PBS and fixed with 2\% glutaraldehyde and $1 \%$ osmium tetroxide for 2 hours at $4^{\circ} \mathrm{C}$, and were dehydrated in a series of ethanol solution $(50 \%, 70 \%, 90 \%, 95 \%$, and $100 \%)$. After infiltration and embedding in epoxy resins at $60^{\circ} \mathrm{C}$ for 48 hours, the sections were stained with lead citrate. Finally, the ultrathin section was observed with the TEM (Philip, Technai 10) operating at $80 \mathrm{kV}$.

\section{Immunofluorescence staining}

Immunofluorescence analyses were used to investigate the role of fullerenes in the expression of cardiac-specific antigens of BADSCs. Briefly, BADSCs were seeded on slides in 24-well culture plate. The cells were treated with fullerenes for 1,3 , and 7 days. The slides were washed and fixed with $4 \%$ paraformaldehyde in $0.1 \mathrm{M}$ phosphate buffer $(\mathrm{pH} 7.4)$ overnight. After permeabilization with $0.1 \%$ Triton X-100, the cells were incubated with the primary antibody against cTnT (Abcam), Cx-43 (Abcam), and $\alpha$-sarcomeric actinin (Actinin, Sigma-Aldrich Co.) overnight at $4^{\circ} \mathrm{C}$, respectively. After rinsing, they were treated with secondary antibodies (FITC-labeled goat anti-mouse $\mathrm{IgG}$ or Cy3-labeled goat anti-mouse $\operatorname{IgG}$ ) at room temperature for 90 minutes. The cell nucleus was stained using DAPI. These samples were observed under a fluorescence microscope (Leica) and analyzed using ImageJ software (NIH, Bethesda, MD, USA).

\section{Western blotting}

After treatment with fullerenes at different concentrations for 1,3 , and 7 days, BADSCs were homogenized in a Laemmli sample buffer (Bio-Rad Laboratories Inc., Hercules, CA, USA) on ice. After centrifugation of the lysates at $12,000 \times g$ for 10 minutes, the supernatant was collected. The protein concentration of these extracts was measured using the BCA ${ }^{\mathrm{TM}}$ Protein Assay Kit (Thermo Scientific). Equal amounts $(75 \mu \mathrm{g})$ of extracted proteins were loaded on a $15 \%$ sodium dodecyl sulfate-polyacrylamide gel and separated by electrophoresis, and then transferred to a polyvinyldiflouride membrane (Roche). The membrane was blocked with 5\% defatted milk for 1 hour at room temperature. Next, the membrane was incubated with primary antibody for rabbit anti-Cx-43, mouse anti- $\alpha$-sarcomeric actinin, mouse antiGAPDH, ERK MAPK rabbit mAb, phospho-ERK MAPK rabbit $\mathrm{mAb}$, p38 MAPK rabbit $\mathrm{mAb}$, and phospho-p38 MAPK rabbit $\mathrm{mAb}$ overnight at $4^{\circ} \mathrm{C}$, and incubated with horseradish peroxidase-coupled goat anti-mouse $\mathrm{IgG} /$ goat anti-rabbit IgG secondary antibodies for 1 hour at room temperature. The signals of protein bands were detected with enhanced chemiluminescence reagent (Applygen, Beijing, People's Republic of China) on X-ray films. Band intensity was normalized with GAPDH as the endogenous control. 


\section{Real-time polymerase chain reaction}

For RNA extraction, total RNA was isolated from cells using TRIpure Reagent (Roche). First-strand cDNA was synthesized using RevertAid First Strand cDNA Synthesis Kit (Thermo Fisher Scientific, Waltham, MA, USA) according to the standard procedures. The real-time polymerase chain reactions were performed in triplicate with the Fast Start Universal SYBR Green Master (ROX; Roche) and run on the Step One PLUS system (Applied Biosystems, Waltham, MA, USA). Results were obtained from three independent experiments, including a no-template control. All primers were designed by the Primer 5 software (Premier Biosoft International, Palo Alto, CA, USA), and include the following: Rat-cTnTF (ggAAgACTggAgCgAAgA), Rat-cTnTR (AAgTTgggCATgAAgAgC), Rat-GAPDHF (gCAAgTTCAAACggCACAg), and Rat-GAPDHR (gCCAgTAgACTCCACgCAT).

\section{Statistical analysis}

All data are expressed as mean \pm SD. Data from the five or six groups were compared, and intergroup differences were analyzed using one-way analysis of variance with Tukey's post hoc test. Statistical analyses were performed with Origin Pro 8 software (Originlab, Northampton, MA, USA). A value of $* P<0.05$ or $* * P<0.01$ was considered statistically significant.

\section{Results and discussion \\ Effects of fullerene on survival of BADSCs}

Of all the carbon nanomaterials, fullerene has the longest history of research on its cytotoxicity. ${ }^{26}$ Cytotoxicity studies were performed by treating BADSCs with fullerene- $\mathrm{C}_{60}$ at different concentrations. AO/PI staining was used to investigate the survival of BADSCs in the presence of fullerene- $\mathrm{C}_{60}$, as shown in Figure 1. The cells growing under all the tested fullerene suspensions were highly viable $(>90 \%)$, and the number of live cells (staining green) gradually increased with culture time. Few dead cells (staining red) were observed in all groups on day 1. Besides, a few dead cells appeared on days $3-7$, especially in the $100 \mu \mathrm{g} / \mathrm{mL}$ group on day 7 , demonstrating the time-dependent and dose-dependent effect.

The presence of apoptotic cells following fullerene- $\mathrm{C}_{60}$ treatment was investigated in a fluorescence-activated cell sorter study. As shown in Figure 2, few apoptotic cells $(\sim 6.13 \%)$ were present in untreated BADSCs on day 3. As expected, the number of apoptotic cells increased after fullerene- $\mathrm{C}_{60}$ treatment. The apoptotic ratio slightly increased at enhanced fullerene- $\mathrm{C}_{60}$ levels. For example, the apoptotic percentage of BADSCs exposed to $100 \mu \mathrm{g} / \mathrm{mL}$ of fullerene- $\mathrm{C}_{60}$ was $-9.91 \%$. These results were consistent with the AO/PI staining. However, the apoptotic percentage was

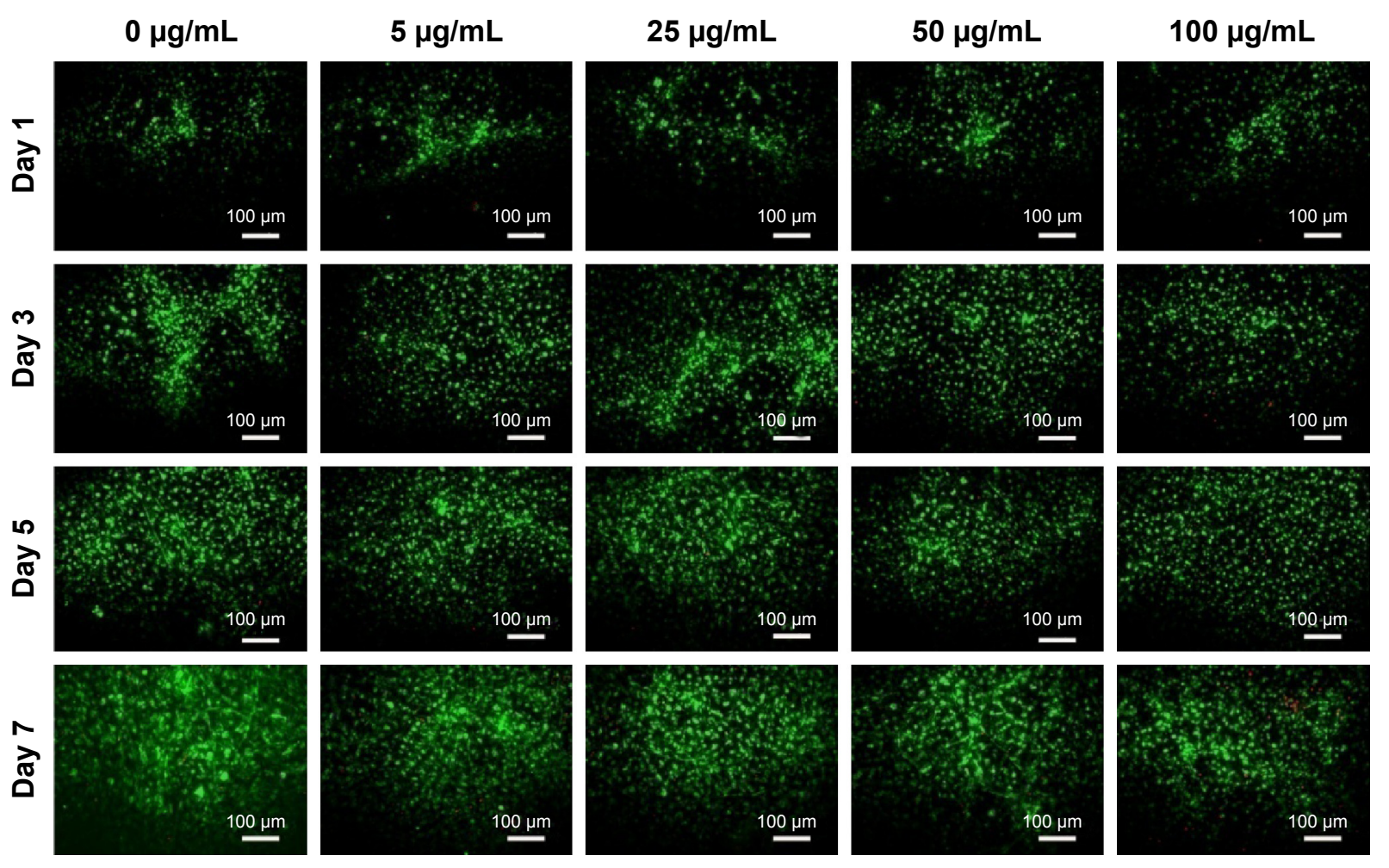

Figure I AO/PI staining images of BADSCs after fullerene- $\mathrm{C}_{60}$ treatment within 7 days.

Abbreviations: $\mathrm{AO}$, acridine orange; PI, propidium iodide; BADSCs, brown adipose-derived stem cells. 


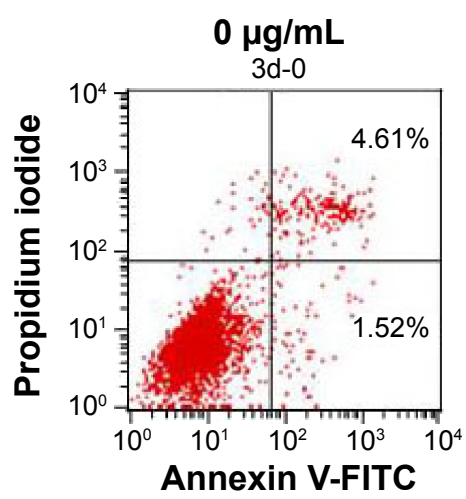

Annexin V-FITC
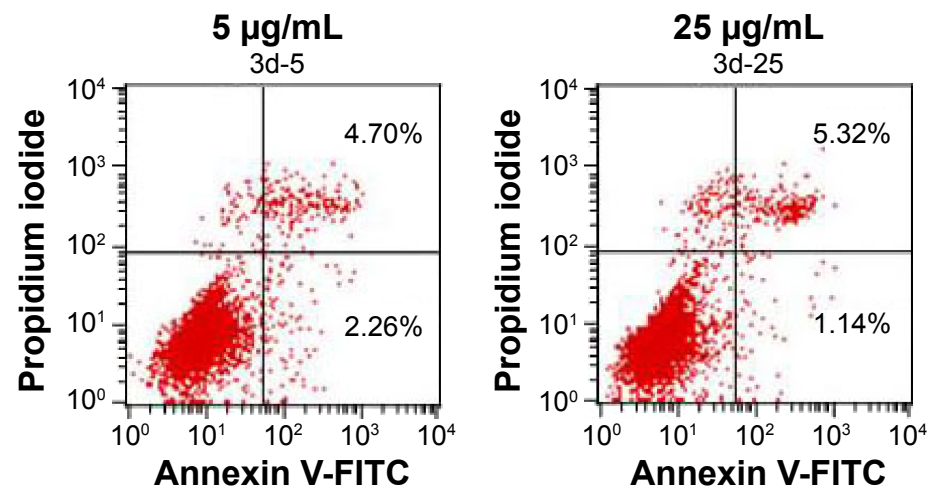
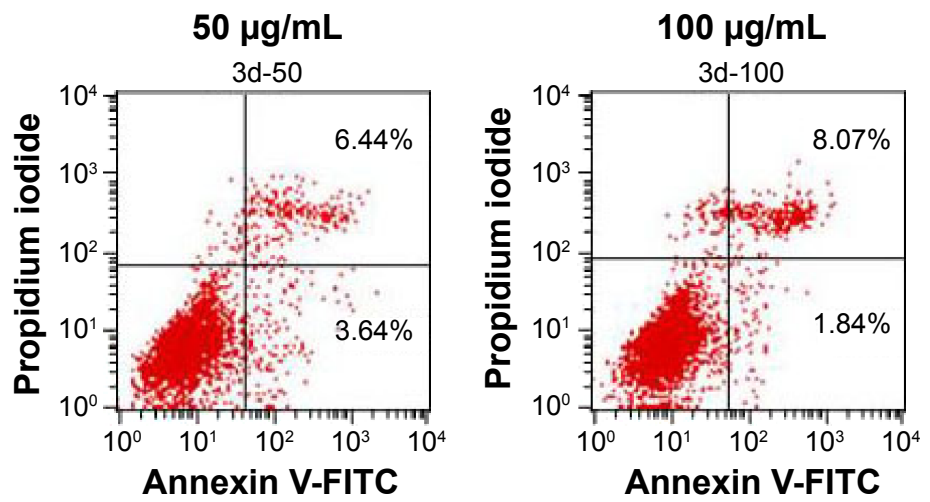

Figure 2 Analysis of apoptotic/dead cell after treatment with fullerene- $C_{60}$ on day 3 by FACS test. Abbreviations: FACS, fluorescence-activated cell sorter; FITC, fluorescein isothiocyanate.

comparatively less than that of other nanomaterials, such as nano- $\mathrm{TiO}_{2}(50 \mu \mathrm{g} / \mathrm{mL}, 23.47 \%),{ }^{27} \mathrm{CNT}(20 \mu \mathrm{g} / \mathrm{mL}, 14.4 \%),{ }^{28}$ and graphene oxide $(50 \mu \mathrm{g} / \mathrm{mL}, 20.4 \%),{ }^{29}$ suggesting minimal damage to BADSCs.

Several studies reported the effect of fullerene- $\mathrm{C}_{60}$ exposure under various experimental conditions using different cell lines, with different results. ${ }^{30}$ For example, Niwa et $\mathrm{al}^{31}$ found that fullerene- $\mathrm{C}_{60}$ decreased the survival and induced micronucleus in Chinese hamster ovary cells, HeLa cells, and human embryonic kidney 293 cells in low doses and following long-term exposure. Fullerene- $\mathrm{C}_{60}$ inhibited nitric oxide production and induced a very low toxicity in human macrophage cells, ${ }^{10,30}$ with a significantly lower cytotoxicity compared with single-wall/multi-wall CNT. ${ }^{32}$ In addition, studies found a dose-dependent toxicity of fullerene- $\mathrm{C}_{60}$. Sayes et a ${ }^{33}$ believed that fullerene- $\mathrm{C}_{60}$ was cytotoxic to human dermal fibroblasts and liver carcinoma cells at the $20 \mathrm{ppb}$ level but was relatively nontoxic at $0.14 \mathrm{ppb}$. Our data suggested that the fullerene- $\mathrm{C}_{60}$ had no cytotoxic effect on BADSCs, even at $100 \mu \mathrm{g} / \mathrm{mL}$.

\section{Cellular uptake of fullerene}

As shown in Figure $\mathrm{S} 4$, fullerene- $\mathrm{C}_{60}$ was spherical. Their size was obviously larger than that of fullerene- $\mathrm{C}_{60}$ molecule $(0.7 \mathrm{~nm})$ owing to the aggregation of fullerene- $\mathrm{C}_{60}$ while preparing the
TEM sample, which is consistent with previous report. ${ }^{34}$ The uptake pathway and cellular localization were established with TEM imaging. Unlike the untreated cells (Figure 3A), many aggregates of the fullerene- $\mathrm{C}_{60}$ nanoparticles were observed as black patches inside the cell (swallow arrow) (Figure 3B and C), which confirmed efficient transfection of fullerene- $\mathrm{C}_{60}$. Further, most of fullerene- $\mathrm{C}_{60}$ accumulation occurred inside the lysosomes. In addition, very few fullerene- $\mathrm{C}_{60}$ nanoparticles were observed between the cells (Figure 3B), indicating that the uptake ratio of fullerene- $\mathrm{C}_{60}$ for BADSCs was high. The fullerene- $\mathrm{C}_{60}$ mechanism of transmission via spontaneous membrane adsorption may be similar to that of other carbon nanomaterials, ${ }^{35}$ and the internalization entails insertion and diffusion of fullerene- $\mathrm{C}_{60}$ across cell membranes. On the other hand, a previous study suggested that lower sized carbon nanomaterials easily penetrated the cell membrane.$^{36}$ Therefore, the diffusion of tiny fullerene- $\mathrm{C}_{60}$ nanoparticles $(\sim 0.7 \mathrm{~nm})$ was easier inside the cells compared with other carbon nanomaterials. The detailed mechanism should be further studied.

\section{Effects of fullerene on the proliferation behavior of BADSCs}

To investigate the proliferative activity of BADSCs in the presence of different concentrations of fullerene- $\mathrm{C}_{60}$, BrdU 

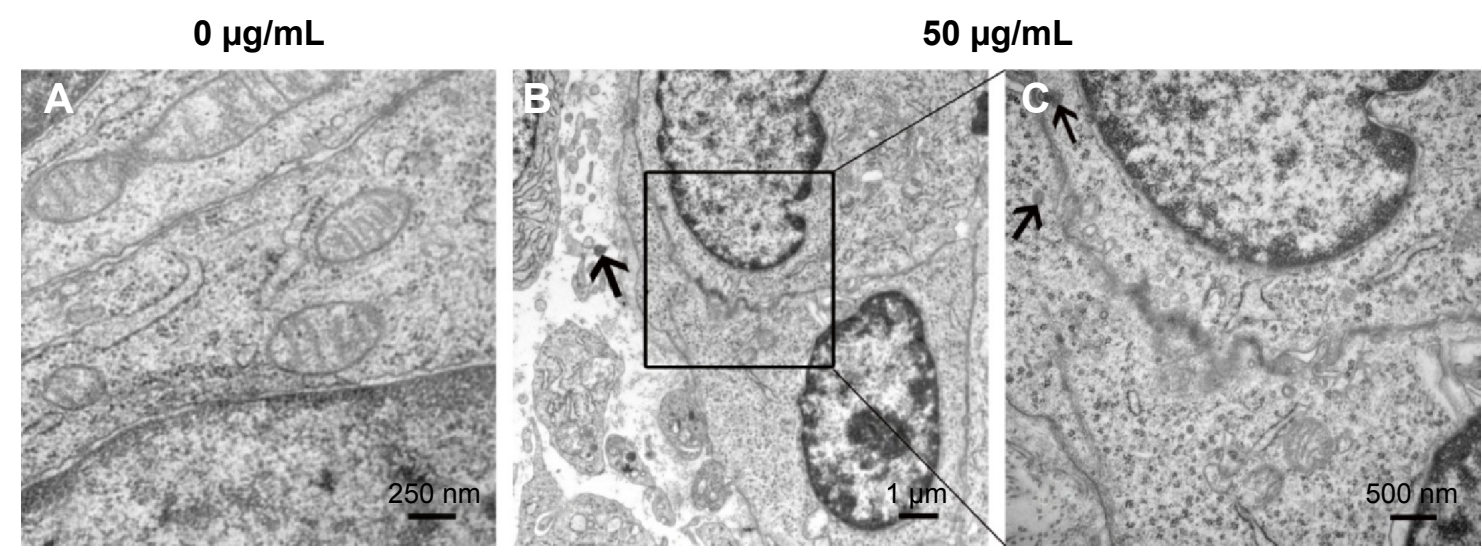

Figure 3 TEM images of BADSCs with and without fullerene- $C_{60}$ treatment.

Notes: (A) Untreated cells. (B) $50 \mu \mathrm{g} / \mathrm{mL}$ fullerene- $\mathrm{C}_{60}$ treated cells. $(\mathbf{C})$ The zoom of selected area in $\mathbf{B}$. The black arrows point to aggregated fullerene- $\mathrm{C}_{60}$ between cells or inside cells.

Abbreviations: TEM, transmission electron microscopy; BADSCs, brown adipose-derived stem cells.

staining was carried out on days 1,3 , and 7. As shown in Figure $4 \mathrm{~A}$ and $\mathrm{B},>9.5 \%$ of cells in all groups were stained by BrdU on day 1. Most BrdU' cells can be observed until day 7 , although the number decreased. Further, the proportion of $\mathrm{BrdU}^{+}$cells in fullerene- $\mathrm{C}_{60}$ groups $(>13.41 \%)$ was significantly higher than that of control $(9.52 \%)$ on day 1 . The proliferative activity increased with increasing fullerene- $\mathrm{C}_{60}$ concentration. The proportion of $\mathrm{BrdU}^{+}$cells after treatment with fullerene- $\mathrm{C}_{60}$ on day 1 with $5,25,50$, and $100 \mu \mathrm{g} / \mathrm{mL}$ was $10.76 \% \pm 1.90 \%, 10.89 \% \pm 0.91 \%, 12.84 \% \pm 1.22 \%$, and

A $0 \mu \mathrm{g} / \mathrm{mL}$
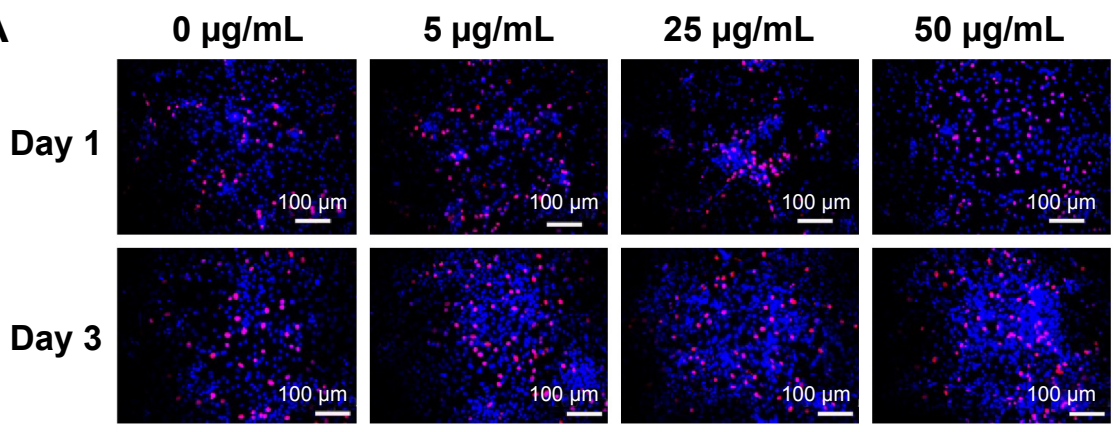

$100 \mu \mathrm{g} / \mathrm{mL}$

Day 3
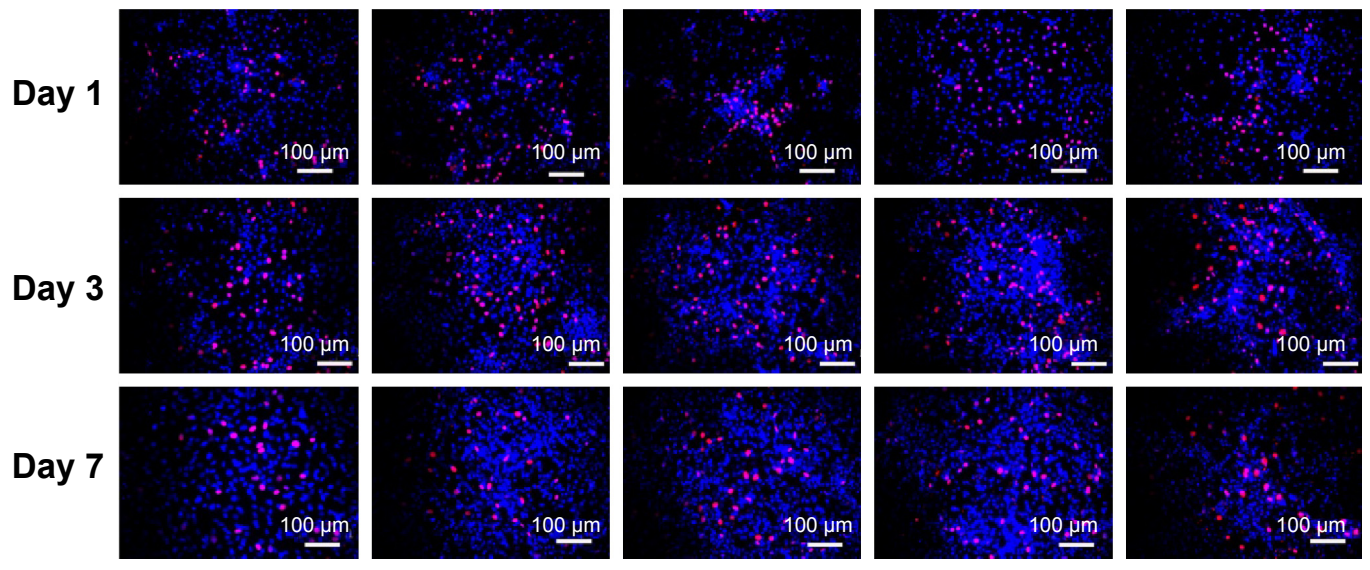

B
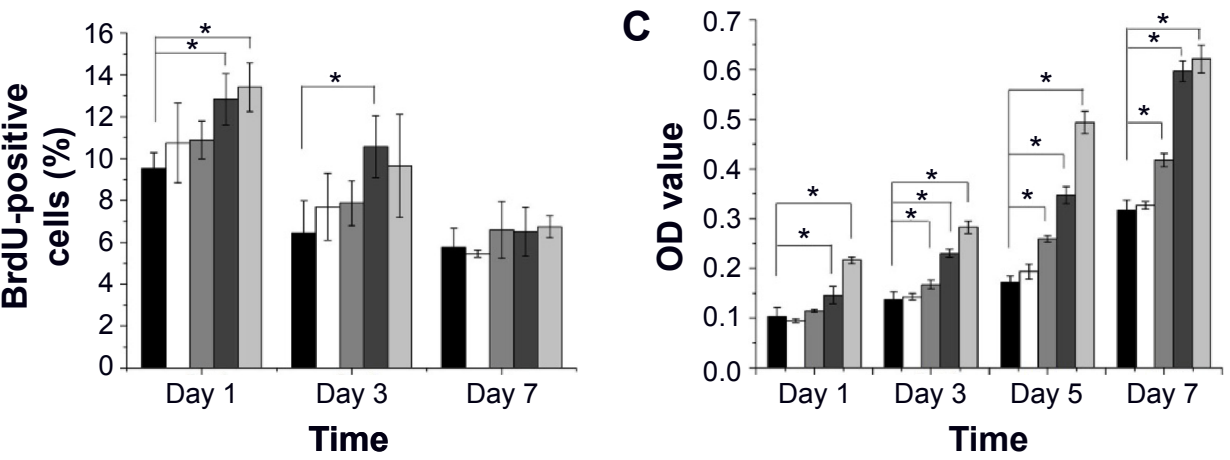

$\square 0 \mu \mathrm{g} / \mathrm{mL} \square 5 \mu \mathrm{g} / \mathrm{mL} \square 25 \mu \mathrm{g} / \mathrm{mL} \square 50 \mu \mathrm{g} / \mathrm{mL} \square 100 \mu \mathrm{g} / \mathrm{mL}$

Figure 4 Effects of fullerene on the proliferation behaviors of BADSCs.

Notes: $(\mathbf{A}) \mathrm{BrdU}$ immunofluorescence staining of BADSCs after treatment with fullerene- $\mathrm{C}_{60^{\circ}}$ (B) Proliferation activity defined as the percentage of BrdU ${ }^{+}$cells relative to the total number of DAPI ${ }^{+}$cells. (C) BADSCs proliferation behaviors for up to 7 days by MTT test. $* P<0.05$.

Abbreviations: BADSCs, brown adipose-derived stem cells; BrdU, bromodeoxyuridine; OD, optical density; DAPI, 4',6-diamidino-2-phenylindole; MTT, 3-(4,5-dimethylthiazol2-yl)-2,5-diphenyltetrazolium bromide. 
$13.41 \% \pm 1.17 \%$, respectively (Figure 4B). In addition, there were no significant differences among all groups on day 7 . Notably, the percentages of $\mathrm{BrdU}^{+}$cells decreased with the extended culture time, probably due to decreased DNA synthesis levels. ${ }^{37}$ Fullerene- $\mathrm{C}_{60}$ treatment partially improved the DNA synthesis in cells, resulting in higher cell number and proliferation. ${ }^{23,38}$

The MTT assay was conducted to measure cell proliferation and viability following exposure to fullerene- $\mathrm{C}_{60}$ for 7 days. As shown in Figure 4C, the cells proliferated constantly in all the groups. The BADSCs showed a higher growth rate within 7 days, and a much larger number of cells in the fullerene- $\mathrm{C}_{60}$ group than in the control group. The number of BADSCs after treatment with $50 \mu \mathrm{g} / \mathrm{mL}$ and $100 \mu \mathrm{g} / \mathrm{mL}$ fullerene- $\mathrm{C}_{60}$ was significantly higher than that of control group on days 5 and 7 , suggesting that fullerene- $\mathrm{C}_{60}$ improved the proliferative capacity.

MAPK plays important roles in cell growth. ${ }^{39}$ In this study, we analyzed the effects of fullerene- $\mathrm{C}_{60}$ on the ERK1/2 MAPK and p38 MAPK pathways on days 1, 3, and 7
(Figure 5A). The phosphorylation of ERK1/2 (p-ERK1/2) is closely related to cell survival (anti-apoptosis) and proliferation. Our present results showed no significant differences in expression of total ERK1/2 in all the experimental groups. However, fullerene- $\mathrm{C}_{60}$ treatment increased the expression levels of phosphorylated ERK1/2 (p-ERK1/2) compared with control group (Figure 5B). Further, the expression of p-ERK1/2 was increased at higher fullerene- $\mathrm{C}_{60}$ levels except for the $100 \mu \mathrm{g} / \mathrm{mL}$ on days 1 and 3, which indicates that fullerene- $\mathrm{C}_{60}$ enhanced the ERK1/2 activities. In addition, fullerene- $\mathrm{C}_{60}$ improved the phosphorylation of p38 (p-p38) (Figure 5C). In a word, the fullerene- $\mathrm{C}_{60}$ entering BADSCs activates ERK1/2 and p38 signaling pathways mediating stem cell survival/proliferation, resulting in improved cell survival and proliferation (Figure 6).

\section{Effect of fullerene on cardiomyogenic differentiation of BADSCs}

Previous studies showed that BADSCs spontaneously differentiated into cardiomyocytes, although the scope for

A
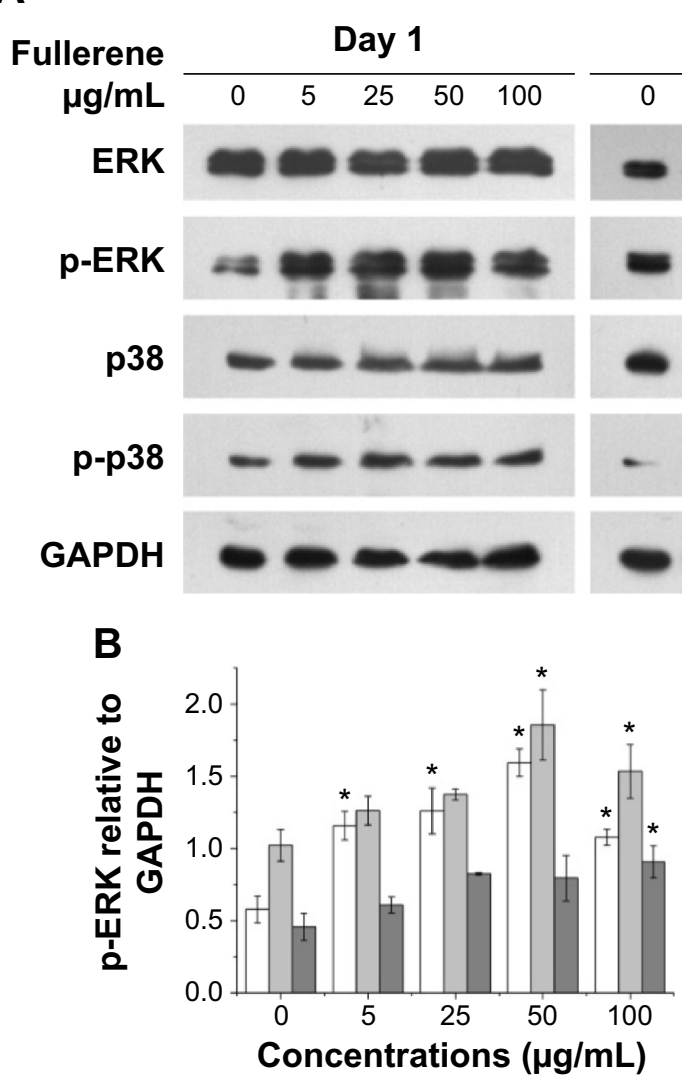

Day 3

\begin{tabular}{lllll}
\hline 0 & 5 & 25 & 50 & 100 \\
0 & 5 & 5 & & 0
\end{tabular}

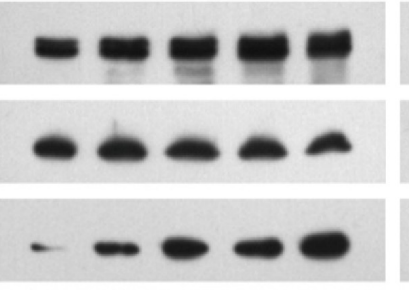

$\infty-\infty$

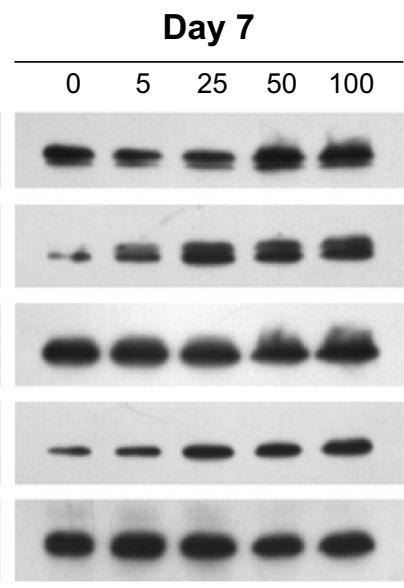

C

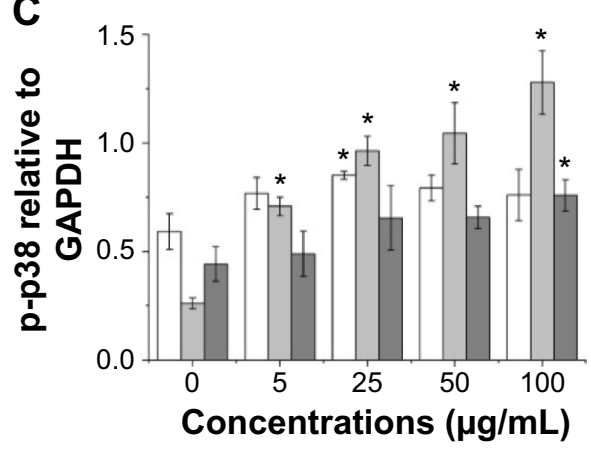

$$
\square 1 \text { day } \square 3 \text { days } \square 7 \text { days }
$$

Figure 5 The effects of fullerene- $C_{60}$ on the ERKI/2 MAPK and P38 MAPK pathways on days I, 3, and 7.

Notes: (A) Representative Western blot assay for detecting the levels of ERK, p-ERK, p38, and p-p38 of BADSCs cultured in the presence of fullerene- ${ }_{60}$. Quantitative analysis of (B) p-ERK expression and (C) p-p38 expression. $* P<0.05$.

Abbreviations: BADSCs, brown adipose-derived stem cells; GAPDH, glyceraldehyde 3-phosphate dehydrogenase. 


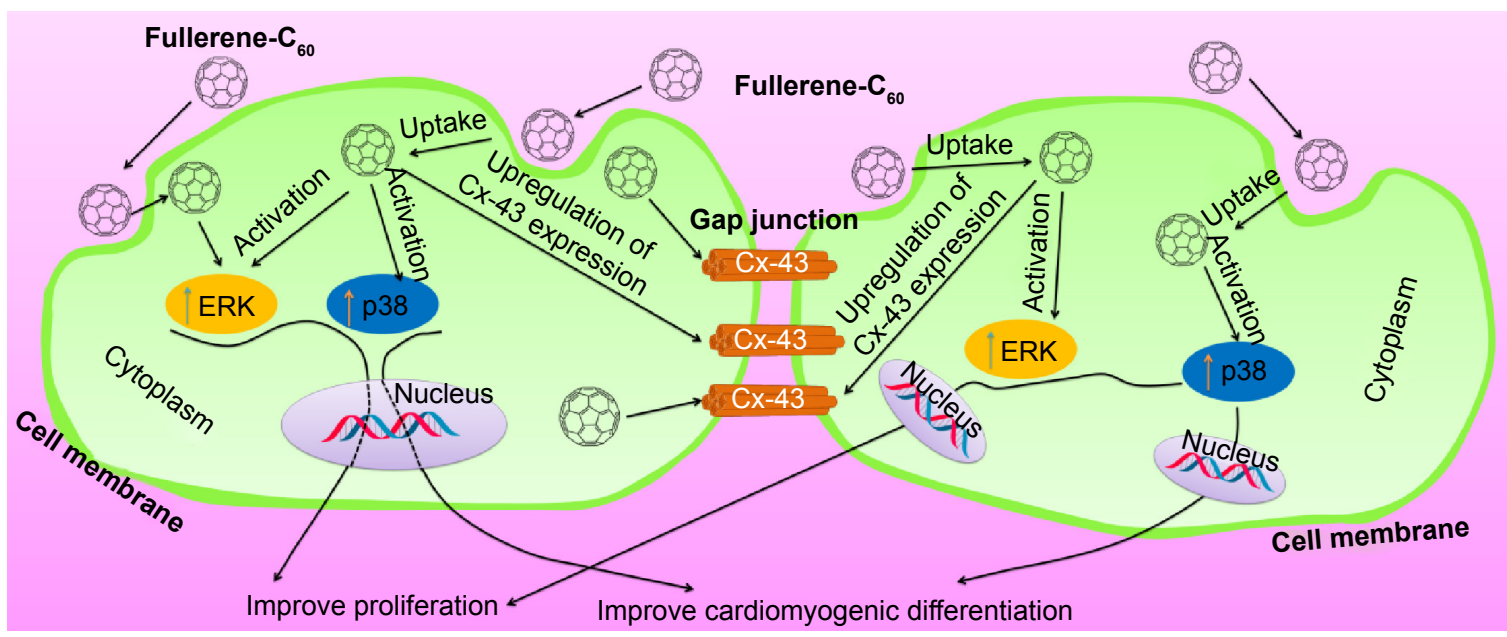

Figure 6 Schematic illustrations of putative pathways for the enhancement of proliferative behaviors and cardiomyogenic differentiation of BADSCs by fullerene- $\mathrm{C}_{60}$ via adjusting the expression of MAPK pathway.

Abbreviations: BADSCs, brown adipose-derived stem cells; MAPK, mitogen-activated protein kinases.

improvement in differentiation efficiency remains. ${ }^{13,14}$ Our previous study found that $1 \mathrm{DCNT}$ and $2 \mathrm{D}$ graphene-based biomaterials improved the cardiac differentiation of BADSCs. ${ }^{21}$ However, the effects of fullerene- $\mathrm{C}_{60}$ on cardiomyogenic differentiation of BADSCs are unknown. We therefore cultured BADSCs in vitro, in a medium containing fullerene- $\mathrm{C}_{60}$ for 1-7 days. Initially, most cells presented fibroblast-like appearance (Figure 7). With increased culture time, elongated morphology and contractile cells were observed in all groups, indicating that some BADSCs differentiated into cardiomyocytes. In addition, the upregulation of $\mathrm{p} 38$ expression is an important signal suggesting cardiomyogenic differentiation of BADSCs. Jong et $\mathrm{al}^{40}$ believe that p38 MAPK signaling facilitates the spontaneous differentiation of embryonic stem cells into cardiomyocytes during the early stage of embryonic development. The control of p38 MAPK activity represented an early switch, committing stem cells into either neurogenesis (p38 off) or cardiomyogenesis (p38 on)..$^{41-43}$ Therefore, fullerene- $\mathrm{C}_{60}$ modulates the cardiomyogenic differentiation of BADSCs by adjusting the expression of $\mathrm{p} 38$ MAPK pathway (Figure 6). In order to further investigate the effects of fullerene- $\mathrm{C}_{60}$ on cardiac differentiation efficiency of BADSCs, the expression of cardiomyocyte-specific proteins (cTnT, $\alpha$-sarcomeric actinin, and $\mathrm{Cx}-43$ ) was determined

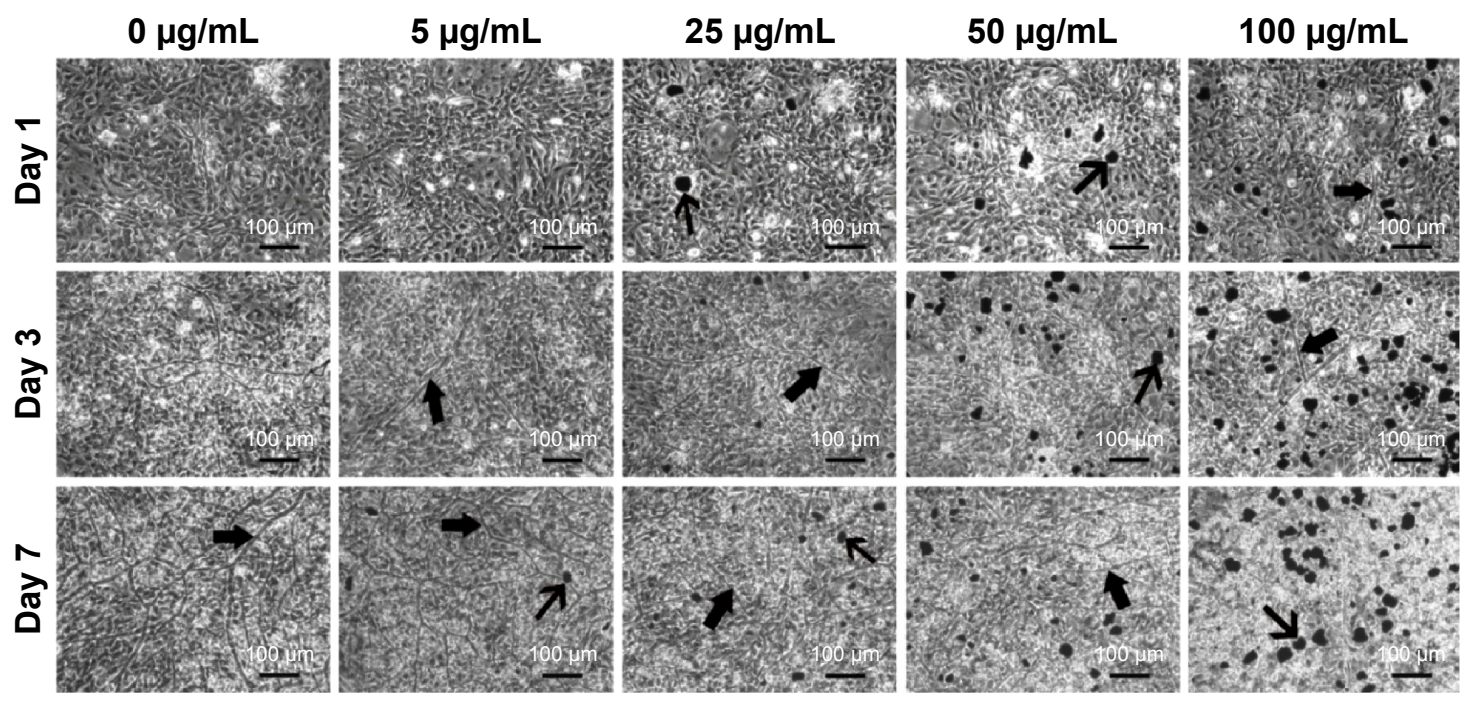

Figure 7 Representative photomicrographs of BADSCs after fullerene- $\mathrm{C}_{60}$ treatment.

Note: The black thin arrows point to aggregated fullerene- $\mathrm{C}_{60}$ and the black thick arrows point to elongated cardiomyocytes.

Abbreviation: BADSCs, brown adipose-derived stem cells. 
via immunofluorescence staining and Western blotting. The degree of $\mathrm{cTnT}$ transcription was also measured by real-time polymerase chain reaction.

Effect of fullerene- $\mathrm{C}_{60}$ on the expression of cTnT As shown in Figure 8A, several cTnT-positive ( $\mathrm{cTnT}^{+}$, green) cells were observed in all the groups on days 1, 3, and 7, indicating differentiation of a few BADSCs into cardiomyocytes. Further, we found a dose- and time-dependent cardiac differentiation of BADSCs. On day 1, the number of $\mathrm{cTnT}^{+}$ cells after treatment with fullerene- $\mathrm{C}_{60}$ was obviously higher than in control groups. The percentage of $\mathrm{cTnT}^{+}$increased from $21.75 \% \pm 6.19 \%$ to $36.40 \% \pm 1.23 \%$ on day 1 when the concentration of fullerene- $\mathrm{C}_{60}$ increased from 0 to $100 \mu \mathrm{g} / \mathrm{mL}$ (Figure 8B), indicating the additional differentiation of BADSCs into cardiomyocytes after treatment with fullerene- $\mathrm{C}_{60}$. The electrical conductivity of fullerene- $\mathrm{C}_{60}$ may be the primary factor driving the differentiation. The percentage of $\mathrm{cTnT}^{+}$cells increased to $38.25 \% \pm 2.98 \%$ in the control group on day 3 , which was higher than in the fullerene- $\mathrm{C}_{60}$ group, suggesting that BADSCs underwent spontaneous cardiomyogenic differentiation. In addition, a shuttle-like morphology of $\mathrm{cTnT}^{+}$cells was observed on day 3 starting with the rounded shape on day 1. Further, these cells were connected with each other and showed striated patterns (inset in Figure 8A), especially in fullerene- $\mathrm{C}_{60}$ groups, which were the typical cardiomyocytes. ${ }^{21}$ On day 7 , the number of $\mathrm{cTnT}^{+}$ cells was obviously reduced in the control group, indicating decrease in the capacity for spontaneous differentiation of BADSCs. Surprisingly, the number of $\mathrm{cTnT}^{+}$cells continued to increase in the $5 \mu \mathrm{g} / \mathrm{mL}$ group.

The effects of fullerene- $\mathrm{C}_{60}$ on the expression of $\mathrm{cTnT}$ were similar to the results with immunofluorescence staining. On day 7 , the expression in the experimental groups (except
A
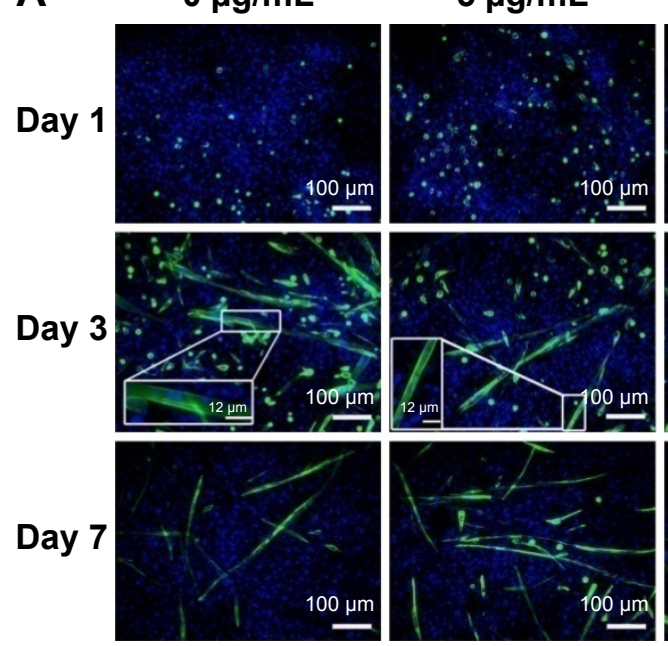

B
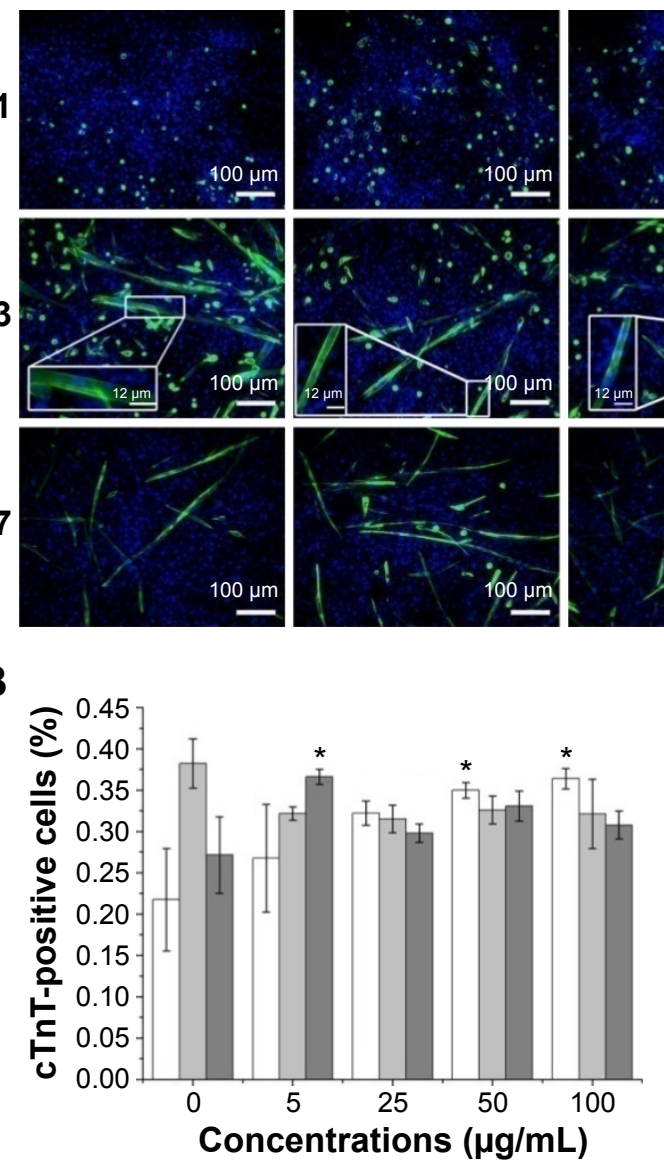

$25 \mu \mathrm{g} / \mathrm{mL}$
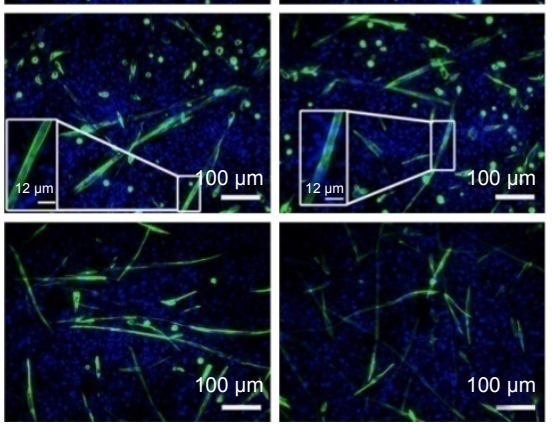

C

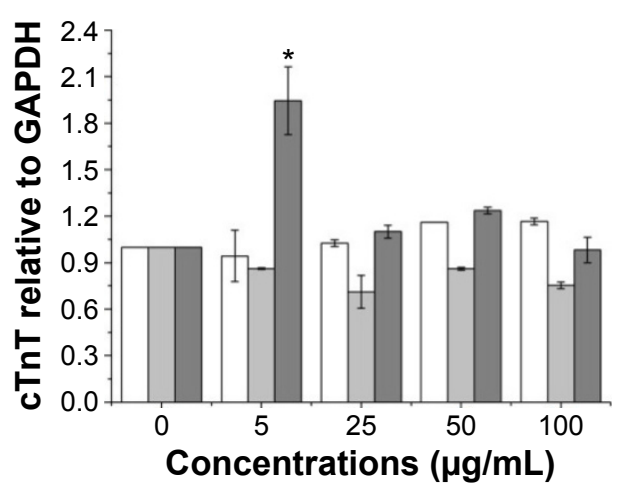

$100 \mu \mathrm{g} / \mathrm{mL}$
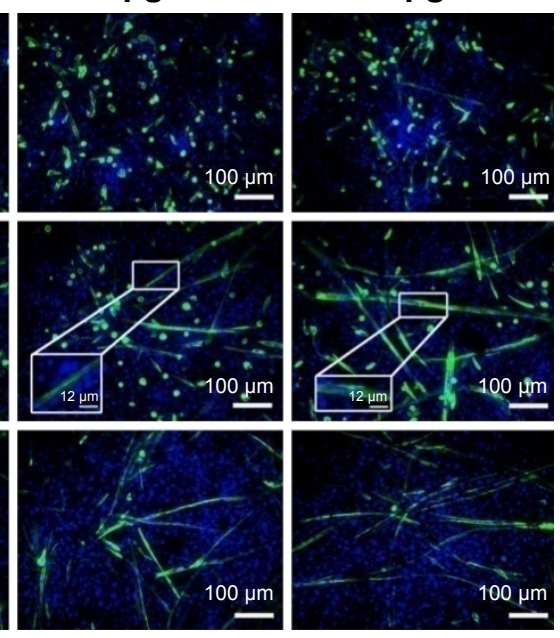

$\square 1$ day $\square 3$ days $\square 7$ days

Figure 8 Effect of fullerene- $\mathrm{C}_{60}$ on the expression of cTnT.

Notes: (A) Immunofluorescence staining micrographs of the BADSCs cultivated in the presence of fullerene- $\mathrm{C}_{60^{\circ}}$ (B) The expression level of cTnT calculated from immunofluorescence staining. (C) The $c T n T$ gene expression by real-time PCR test. ${ }^{*} P<0.05$.

Abbreviations: BADSCs, brown adipose-derived stem cells; PCR, polymerase chain reaction; GAPDH, glyceraldehyde 3-phosphate dehydrogenase. 
$100 \mu \mathrm{g} / \mathrm{mL}$ ) was higher than that of the control group, especially at a concentration of $5 \mu \mathrm{g} / \mathrm{mL}$. However, the gene expression was at odds with that of the protein levels at similar time points, consistent with the results of Gao et al, ${ }^{44}$ who found that the cTnT protein expression was upregulated between test groups and controls, without any significant differences in mRNA expression.
Effect of fullerene- $\mathrm{C}_{60}$ on the expression of $\alpha$-sarcomeric actinin

The expression of the cardiac marker $\alpha$-sarcomeric actinin was similar to that of cTnT, as shown in Figure 9A. The $\alpha$-sarcomeric actinin-positive cells (green) were observed in all groups, especially in 50 and $100 \mu \mathrm{g} / \mathrm{mL}$ fullerene- $\mathrm{C}_{60}$ groups on day 3 . Western blot test also suggested that the

A
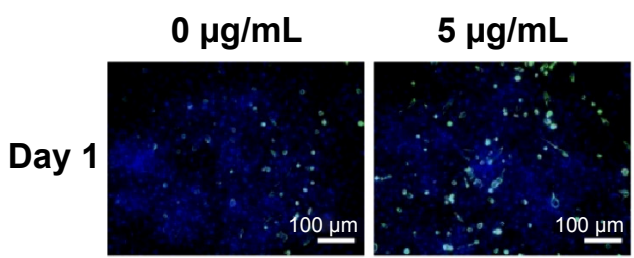

$25 \mu \mathrm{g} / \mathrm{mL}$

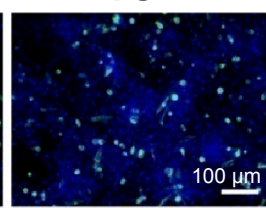

$50 \mu \mathrm{g} / \mathrm{mL}$ $100 \mu \mathrm{g} / \mathrm{mL}$
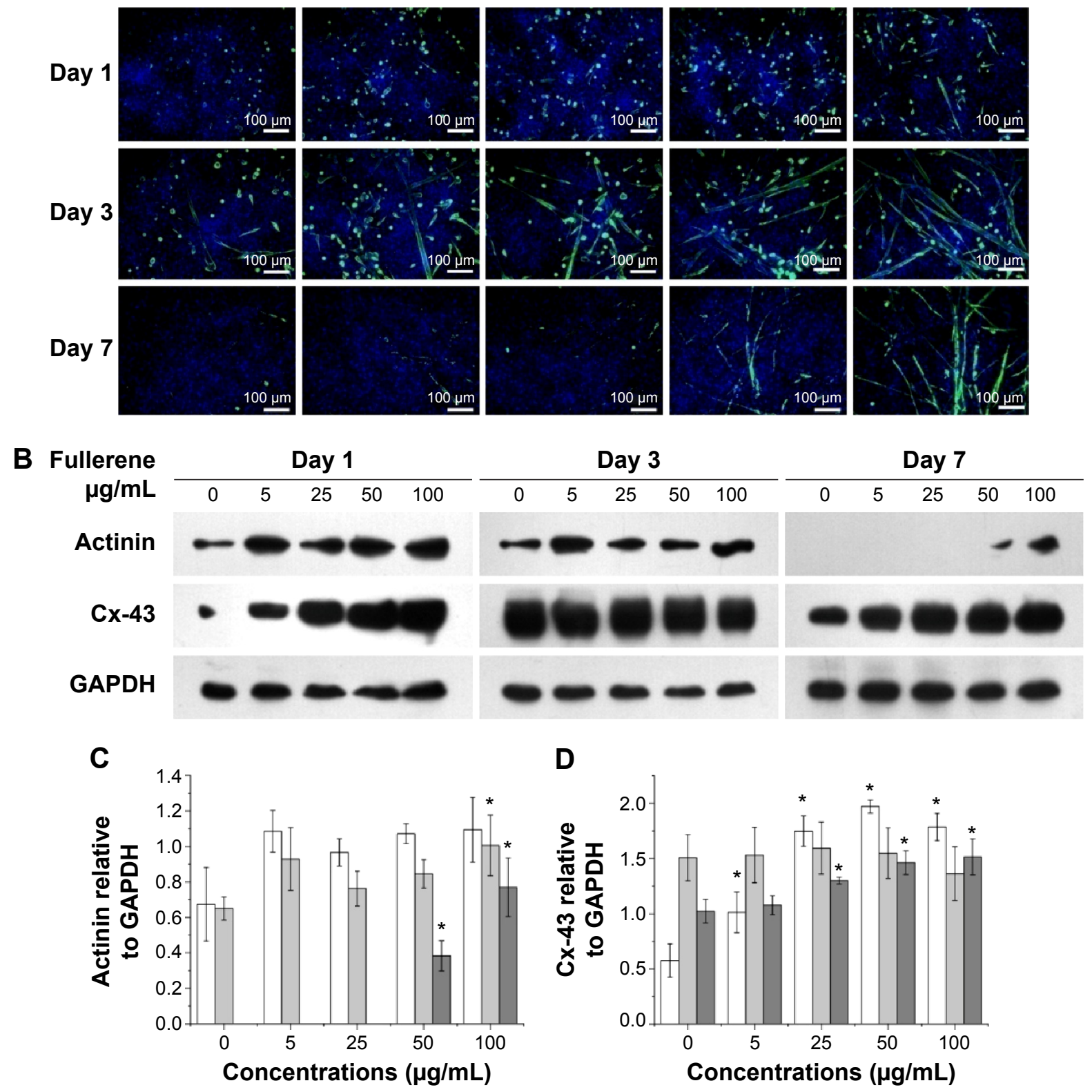

\section{$\square 1$ day $\square 3$ days $\square 7$ days}

Figure 9 Effect of fullerene- $C_{60}$ on the BADSCs' cardiac differentiation.

Notes: (A) Immunofluorescence micrographs of the BADSCs cultivated in the presence of fullerene- $C_{60}$ for $\alpha$-sarcomeric actinin and nucleus. (B) Representative Western blot assay for detecting the levels of $\alpha$-sarcomeric actinin and $C_{x}-43$ of BADSCs after treatment with fullerene- $C_{60}$. Quantitative analysis of (C) $\alpha$-sarcomeric actinin expression levels and (D) $C x-43$ expression levels. $* P<0.05$.

Abbreviations: BADSCs, brown adipose-derived stem cells; GAPDH, glyceraldehyde 3-phosphate dehydrogenase. 


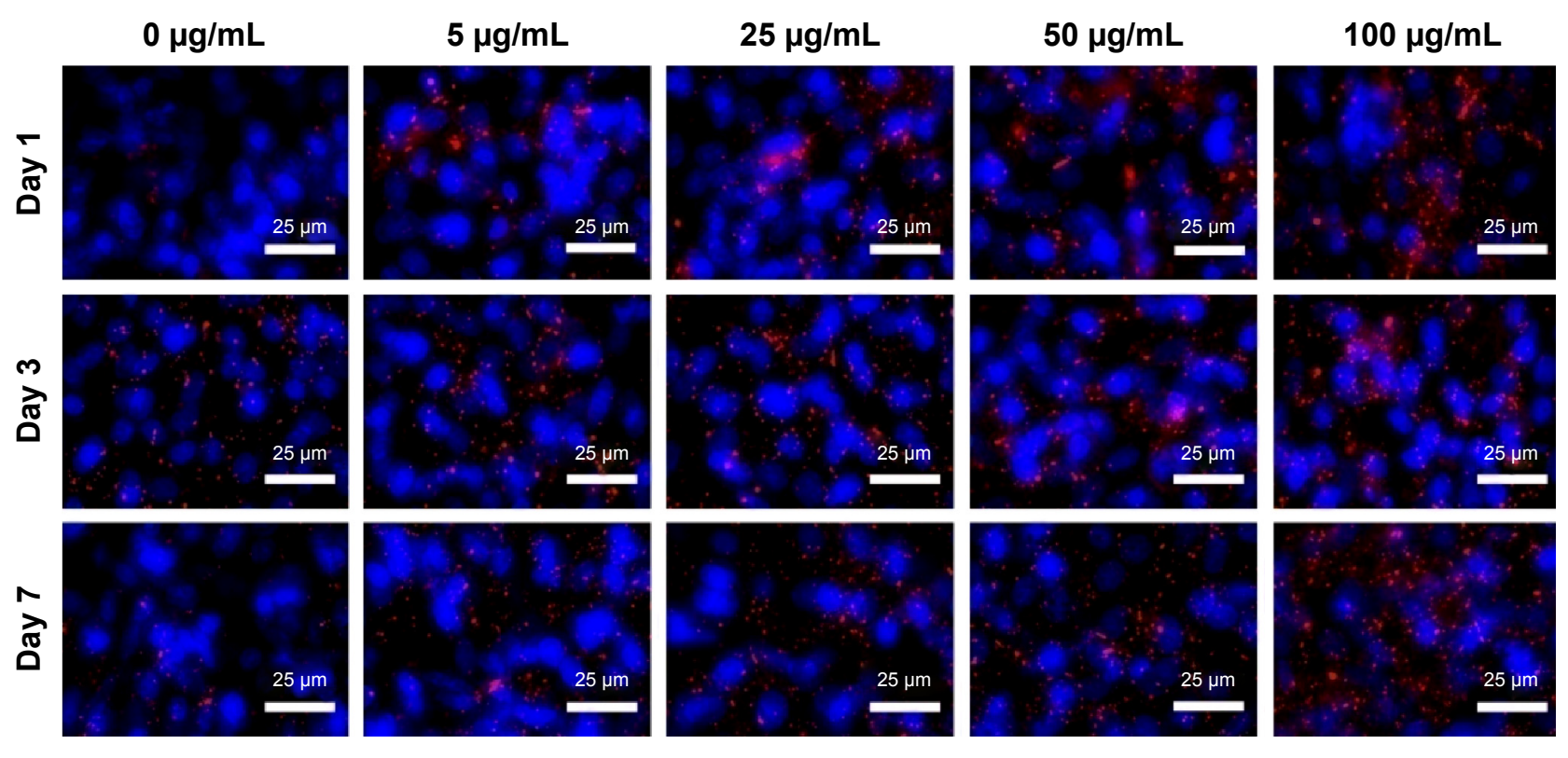

Figure 10 Immunofluorescence staining micrographs of the BADSCs cultivated in the presence of fullerene- $C_{60}$ for $C_{x}-43$ and nucleus. Abbreviation: BADSCs, brown adipose-derived stem cells.

fullerene- $\mathrm{C}_{60}$ improved the expression of $\alpha$-sarcomeric actinin (Figure 9B), and the expression level decreased with culture time. Further, limited $\alpha$-sarcomeric actinin expression was observed in the $0-25 \mu \mathrm{g} / \mathrm{mL}$ group on day 7 , but the cells in 50 and $100 \mu \mathrm{g} / \mathrm{mL}$ groups showed an elevated expression of $\alpha$-sarcomeric actinin. These results suggest that the spontaneous cardiac differentiation of BADSCs decreased with time, which was prevented by high concentrations of fullerene- $\mathrm{C}_{60}$. Because fullerene- $\mathrm{C}_{60}$ can be easily taken up by BADSCs, it can further mediate cardiomyogenic differentiation via modulation of the expression of $\mathrm{p} 38$ pathway and cardiac protein expression.

\section{Effect of fullerene- $C_{60}$ on $\mathrm{Cx}-43$ expression}

The gap junction protein $\mathrm{Cx}-43$, which is responsible for electrical and mechanical coupling, ${ }^{45}$ plays critical roles in cell growth and differentiation. It is the most widely expressed as well as the most representative of cardiac myocytes gap junctions, and enables cell-to-cell communication. Immunofluorescence staining showed that $\mathrm{Cx}-43$ was expressed around the edges of the cells in all groups (Figure 10). Moreover, the Western blot revealed that the $\mathrm{Cx}-43$ expression level in the control group was lower than in fullerene- $\mathrm{C}_{60}$ groups at all time points (Figure 9C). No statistical differences were seen among fullerene- $\mathrm{C}_{60}$ groups on day 1 , while the expression level of $\mathrm{Cx}-43$ increased with rising level of fullerene- $\mathrm{C}_{60}$. These results indicate that the fullerene- $\mathrm{C}_{60}$ was beneficial for the formation of gap junctions among cells and further improved the cell-cell communication (Figure 6). TEM images also showed the formation of gap junction. As shown in Figure 11, the BADSCs-derived cardiac-like cells showed more compact gap junctions at $50 \mu \mathrm{g} / \mathrm{mL}$ fullerene- $\mathrm{C}_{60}$ than in control group (the crude arrows). The results suggested that fullerene- $\mathrm{C}_{60}$ enhanced the cardiac differentiation of BADSCs, and promoted the maturation of cardiac-like cells, in relation to the electrical conductivity of carbon nanomaterials.

\section{Conclusion}

In summary, our findings provide evidence supporting the role of fullerene- $\mathrm{C}_{60}$ in modulating the proliferation and cardiomyogenic differentiation of rat BADSCs. The fullerene- $\mathrm{C}_{60}$ nanomaterials do not induce the cytotoxicity in BADSCs even at high concentrations $(100 \mu \mathrm{g} / \mathrm{mL})$. In addition, fullerene- $\mathrm{C}_{60}$ easily transfects cells and modulates the expression of MAPK signaling (ERK and p38) related to stem cell survival, proliferation, and cardiomyogenesis, thereby enhancing proliferative activity of BADSCs. Further, fullerene- $\mathrm{C}_{60}$ improves cardiomyogenic differentiation of BADSCs. It promotes the formation of gap junctions in cells and further improves the cell-cell communication. These results provide an opportunity to enhance the proliferation and cardiomyogenic differentiation of stem cells, and suggest evidence for the potential application of fullerene- $\mathrm{C}_{60}$ in the treatment of MI via cell therapy or tissue engineering. 


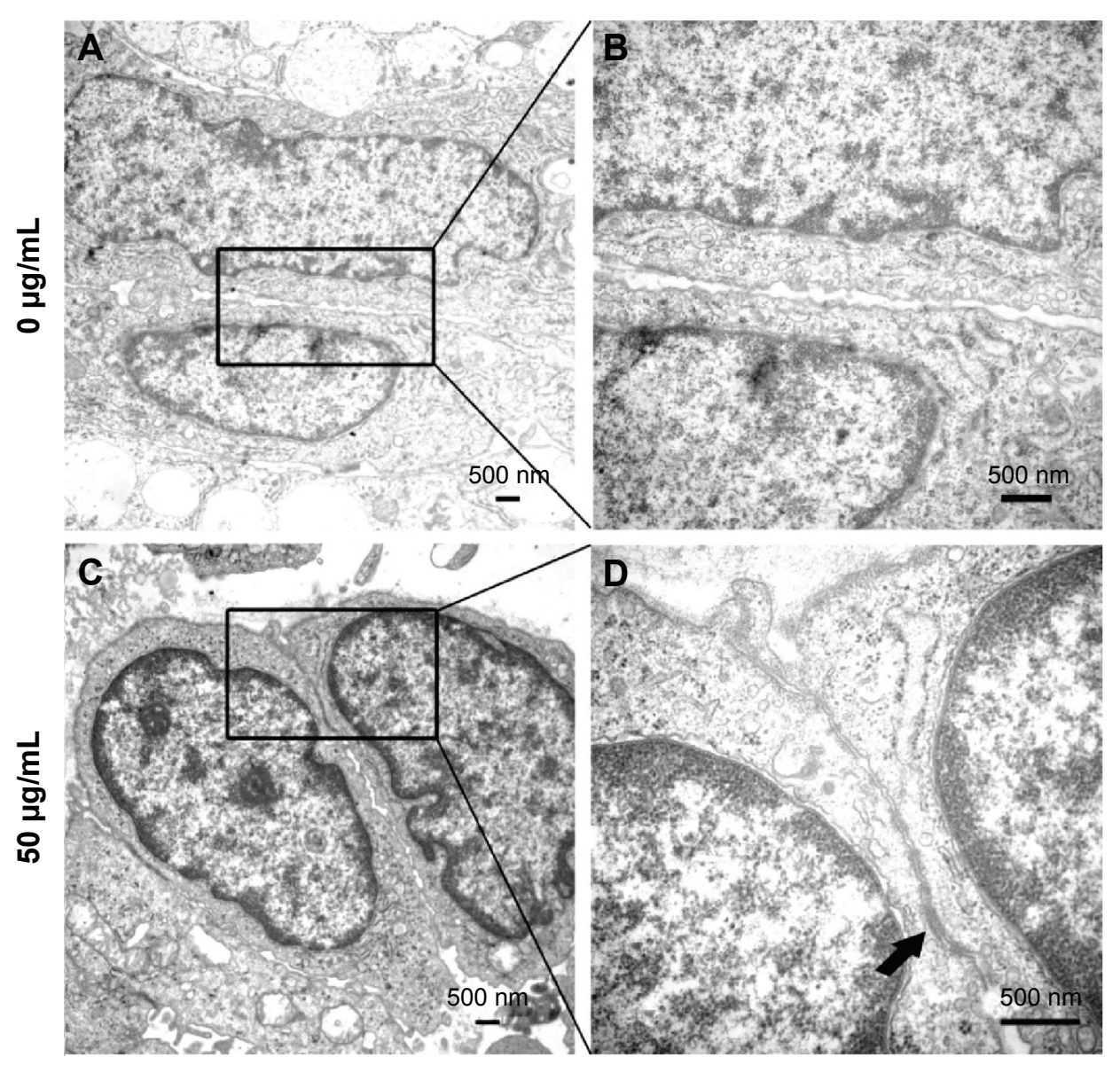

Figure II TEM images of the formation of gap junctions in BADSCs.

Notes: (A), (B) Untreated BADSCs. (C), (D) BADSCs treated with $50 \mu \mathrm{g} / \mathrm{mL}$ fullerene. (B), (D) are the zoom of (A) and (C). The thick arrow shows the gap junctions between cells.

Abbreviations: TEM, transmission electron microscopy; BADSCs, brown adipose-derived stem cells.

\section{Acknowledgments}

This work was supported by the National Natural Science Funds for Distinguished Young Scholar (No 31125013), National Key Basic Research and Development Program of China (No 2011CB606206), International Cooperation and Exchanges NSFC (No 31320103914), Key Program of National Natural Science Foundation of China (No 31030032), National Natural Science Foundation of China (No 31370975 , No 31200733, No 31100674, No 31370987, No 31470940), and National High Technology Research and Development Program of China (No SS2015AA020304).

\section{Disclosure}

The authors report no conflicts of interest in this work.

\section{References}

1. Stout DA, Webster TJ. Carbon nanotubes for stem cell control. Mater Today. 2012;15:312-318.

2. Ku SH, Lee M, Park CB. Carbon-based nanomaterials for tissue engineering. Adv Healthcare Mater. 2013;2:244-260.
3. Talukdar Y, Rashkow JT, Lalwani G, et al. The effects of graphene nanostructures on mesenchymal stem cells. Biomaterials. 2014;35: 4863-4877.

4. Cheng LC, Jiang XM, Wang J, et al. Nano-bio effects: interaction of nanomaterials with cells. Nanoscale. 2013;5:3547-3569.

5. Nakanishi W, Minamia K, Shresthaa LK, et al. Bioactive nanocarbon assemblies: nanoarchitectonics and applications. Nano Today. 2014;9: 378-394.

6. Kroto HW, Heath JR, Obrien SC, et al. C60: Buckminsterfullerene. Nature. 1985;318:162-163.

7. Raoof M, Mackeyev Y, Cheney MA, Wilson LJ, Curley SA. Internalization of $\mathrm{C} 60$ fullerenes into cancer cells with accumulation in the nucleus via the nuclear pore complex. Biomaterials. 2012;33:2952-2960.

8. Grausova L, Vacik J, Vorlicek V, et al. Fullerene $\mathrm{C}_{60}$ films of continuous and micropatterned morphology as substrates for adhesion and growth of bone cells. Diam Relat Mater. 2009;18:578-586.

9. Markovic Z, Trajkovic V. Biomedical potential of the reactive oxygen species generation and quenching by fullerenes $\left(\mathrm{C}_{60}\right)$. Biomaterials. 2008;29:3561-3573.

10. Fiorito S, Serafino A, Andreola F, et al. Effects of fullerenes and singlewall carbon nanotubes on murine and human macrophages. Carbon. 2006;44:1100-1105.

11. Nishimura T, Kubota R, Tahara M, et al. Biological effects of fullerene C60 in mouse embryonic stem cells. Toxicol Lett. 2006;164S:S214.

12. Park J, Kim B, Han J, et al. Graphene oxide flakes as a cellular adhesive: prevention of reactive oxygen species mediated death of implanted cells for cardiac repair. ACS Nano. 2015;9:4987-4999. 
13. Wang HB, Shi JX, Wang Y, et al. Promotion of cardiac differentiation of brown adipose derived stem cells by chitosan hydrogel for repair after myocardial infarction. Biomaterials. 2014;35:3986-3998.

14. Liu ZQ, Wang HB, Wang Y, et al. The influence of chitosan hydrogel on stem cell engraftment, survival and homing in the ischemic myocardial microenvironment. Biomaterials. 2012;33:3093-3106.

15. Han J, Kim B, Shin JY, et al. Iron oxide nanoparticle-mediated development of cellular gap junction crosstalk to improve mesenchymal stem cells' therapeutic efficacy for myocardial infarction. ACS Nano. 2015;9: 2805-2819.

16. Psaltis PJ, Zannettino AC, Worthley SG, et al. Concise review: mesenchymal stromal cells: potential for cardiovascular repair. Stem Cells. 2008;26:2201-2210

17. Kang SJ, Kim BM, Lee YJ, et al. Titanium dioxide nanoparticles induce apoptosis through the $\mathrm{JNK} / \mathrm{p} 38$-caspase-8-Bid pathway in phytohemagglutinin-stimulated human lymphocytes. Biochem Biophys Res Commun. 2009;386:682-687.

18. Liang X, So YH, Cui JW, et al. The low-dose ionizing radiation stimulates cell proliferation via activation of the MAPK/ERK pathway in rat cultured mesenchymal stem cells. J Radiat Res. 2011;52:380-386.

19. Park J, Park S, Ryu S, et al. Graphene-regulated cardiomyogenic differentiation process of mesenchymal stem cells by enhancing the expression of extracellular matrix proteins and cell signaling molecules. Adv Healthcare Mater. 2014;3:176-181.

20. Mooney E, Mackle JN, Blond DJP, et al. The electrical stimulation of carbon nanotubes to provide a cardiomimetic cue to MSCs. Biomaterials. 2012;33:6132-6139.

21. Li X, Zhou J, Liu ZQ, et al. A PNIPAAm-based thermosensitive hydrogel containing SWCNTs for stem cell transplantation in myocardial repair. Biomaterials. 2014;35:5679-5688.

22. Sun HY, Lü SH, Jiang XX, et al. Carbon nanotubes enhance intercalated disc assembly in cardiac myocytes via the $\beta 1$-integrin-mediated signaling pathway. Biomaterials. 2015;55:84-95.

23. Yang Z, Li CJ, Wan Y, et al. Antioxidative fullerol promotes osteogenesis of human adipose-derived stem cells. Int J Nanomed. 2014;9: 4023-4031.

24. Yamada Y, Wang XD, Yokoyama S, et al. Cardiac progenitor cells in brown adipose tissue repaired damaged myocardium. Biochem Biophys Res Commun. 2006;342:662-670.

25. Liu ZQ, Wang HB, Zhang Y, et al. Efficient isolation of cardiac stem cells from brown adipose. J Biomed Biotechnol. 2010;2010:104296.

26. Tokuyama H, Yamago S, Nakamura E, et al. Photoinduced biochemical activity of fullerene carboxylic acid. J Am Chem Soc. 1993;115: 7918-7919.

27. Liu S, Xu L, Zhang T, et al. Oxidative stress and apoptosis induced by nanosized titanium dioxide in PC12 cells. Toxicology. 2010;267: $172-177$.

28. Guo YY, Zhang J, Zheng YF, et al. Cytotoxic and genotoxic effects of multi-wall carbon nanotubes on human umbilical vein endothelial cells in vitro. Mutat Res. 2011;721:184-191.

29. Zhang W, Yan L, Li M, et al. Deciphering the underlying mechanisms of oxidation-state dependent cytotoxicity of graphene oxide on mammalian cells. Toxicol Lett. 2015;237:61-71.
30. Lewinski N, Colvin V, Drezek R. Cytotoxicity of nanoparticles. Small. 2008;4:26-49.

31. Niwa Y, Iwai N. Genotoxicity in cell lines induced by chronic exposure to water-soluble fullerenes using micronucleus test. Environ Health Prev Med. 2006;11:292-297.

32. Jia G, Wang H, Yan L, et al. Cytotoxicity of carbon nanomaterials: single-wall nanotube, multi-wall nanotube, and fullerene. Environ Sci Technol. 2005;39:1378-1383.

33. Sayes CM, Fortner JD, Guo W, et al. The differential cytotoxicity of water-soluble fullerenes. Nano Lett. 2004;4:1881-1887.

34. Lao F, Chen L, Wei Li, et al. Fullerene nanoparticles selectively enter oxidation-damaged cerebral microvessel endothelial cells and inhibit JNK related apoptosis. ACS Nano. 2009;3:3358-3368.

35. Lopez CF, Nielsen SO, Moore PB, et al. Understanding nature's design for a nanosyringe. Proc Natl Acad Sci US A. 2004;101:4431-4434.

36. Raffa V, Ciofani G, Nitodas $\mathrm{S}$, et al. Can the properties of carbon nanotubes influence their internalization by living cells? Carbon. 2008;46: $1600-1610$.

37. Xing Y, Xiong W, Zhu L, et al. DNA damage in embryonic stem cells caused by nanodiamonds. ACS Nano. 2011;5:2376-2384.

38. Liu H, Yang X, Zhang Y, et al. Fullerol antagonizes dexamethasoneinduced oxidative stress and adipogenesis while enhancing osteogenesis in a cloned bone marrow mesenchymal stem cell. J Orthop Res. 2012; 30:1051-1057.

39. Chi J, Zhu Y, Fu Y, et al. Cyclosporina induces apoptosis in H9C2 cardiomyoblast cells through calcium-sensing receptor-mediated activation of the ERK MAPK and p38 MAPK pathways. Mol Cell Biochem. 2012;367:227-236.

40. De Jong AM, Maass AH, Oberdorf-Maass SU, et al. Cyclical stretch induces structural changes in atrial myocytes. J Cell Mol Med. 2013;17: $743-753$.

41. Aouadi M, Bost F, Caron L, et al. p38 mitogen-activated protein kinase activity commits embryonic stem cells to either neurogenesis or cardiomyogenesis. Stem Cells. 2006;24:1399-1406.

42. Wu J, Kubota J, Hirayama J, et al. p38 mitogen-activated protein kinase controls a switch between cardiomyocyte and neuronal commitment of murine embryonic stem cells by activating myocyte enhancer factor 2C-dependent bone morphogenetic protein 2 transcription. Stem Cells Dev. 2010;19:1723-1734.

43. Barruet E, Hadadeh O, Peiretti F, et al. p38 mitogen activated protein kinase controls two successive-steps during the early mesodermal commitment of embryonic stem cells. Stem Cells Dev. 2011;20: 1233-1246.

44. Gao Y, Connell JP, Wadhwa L, et al. Amniotic fluid-derived stem cells demonstrated cardiogenic potential in indirect co-culture with human cardiac cells. Ann Biomed Eng. 2014;42:2490-2500.

45. Dvir T, Levy O, Shachar M, et al. Activation of the ERK1/2 cascade via pulsatile interstitial fluid flow promotes cardiac tissue assembly. Tissue Eng. 2007;13:2185-2193. 


\section{Supplementary materials}

As shown in Figure S1, the expression of CD29 and CD90 is $53.49 \%$ and $50.77 \%$ for characteristic of mesenchymal stem cells, respectively, which is consistent with previous report. ${ }^{1}$ In addition, most of the cells were negative for CD45, CD133, and CD34 (which are the hematopoietic markers and endothelial cells markers). ${ }^{2}$ These data are consistent with immunophenotypic markers of MSCs.

In order to investigate the differentiation potential of BADSCs, the isolated cells were cultured under adipogenic or osteogenic microenvironment for 7 and 14 days, respectively. As shown in Figure S2, cells cultured under
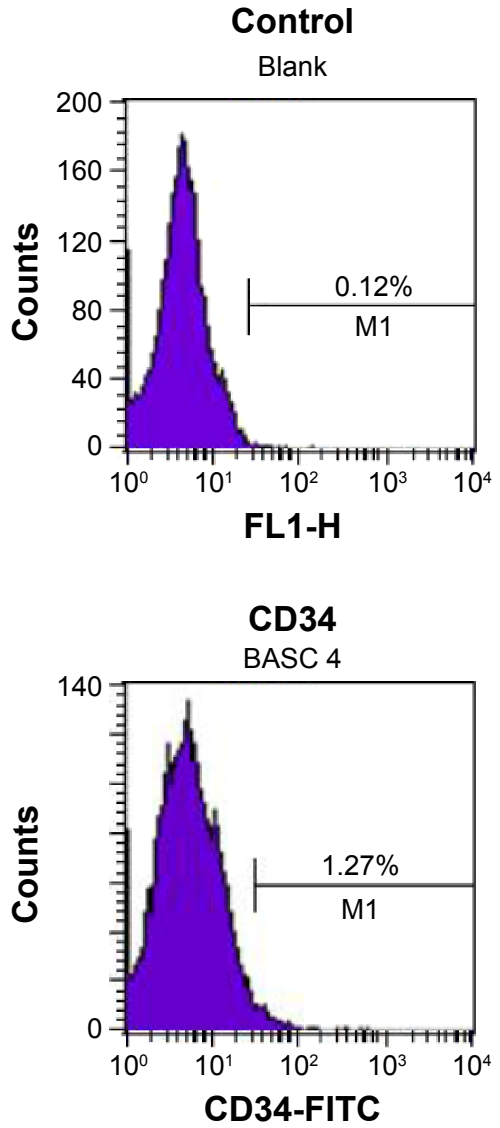

CD29

BASC 1

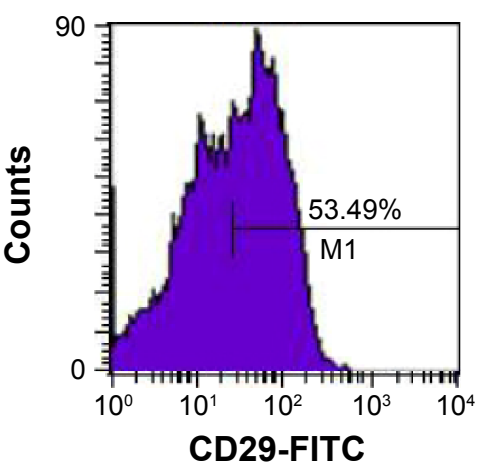

CD45

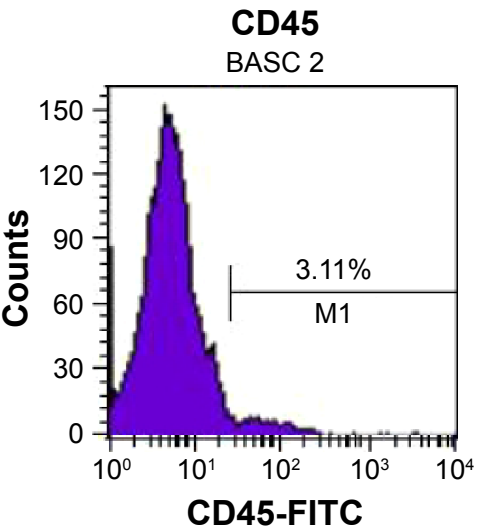

CD90

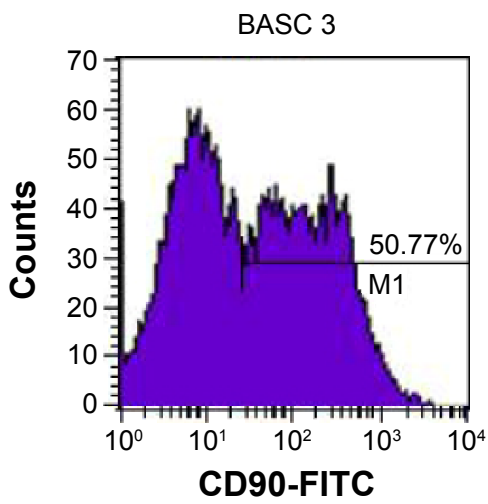

CD133

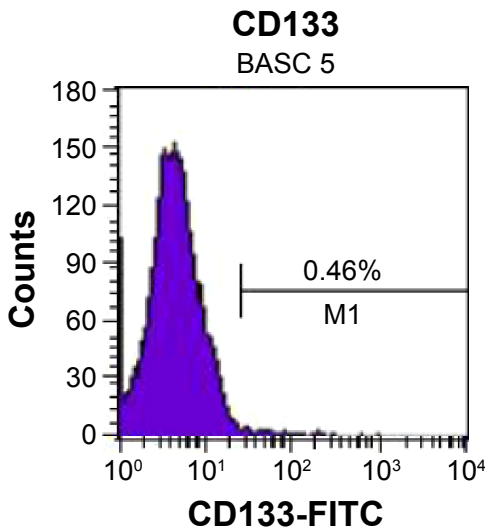

Figure SI Flow cytometric analysis of BADSCs.

Note: The cells are positive for CD29 and CD90 for characteristic of mesenchymal stem cells, but negative for CD34, CD45, and CDI33.

Abbreviations: BADSCs, brown adipose-derived stem cells; FITC, fluorescein isothiocyanate; MI, number of positive cells.
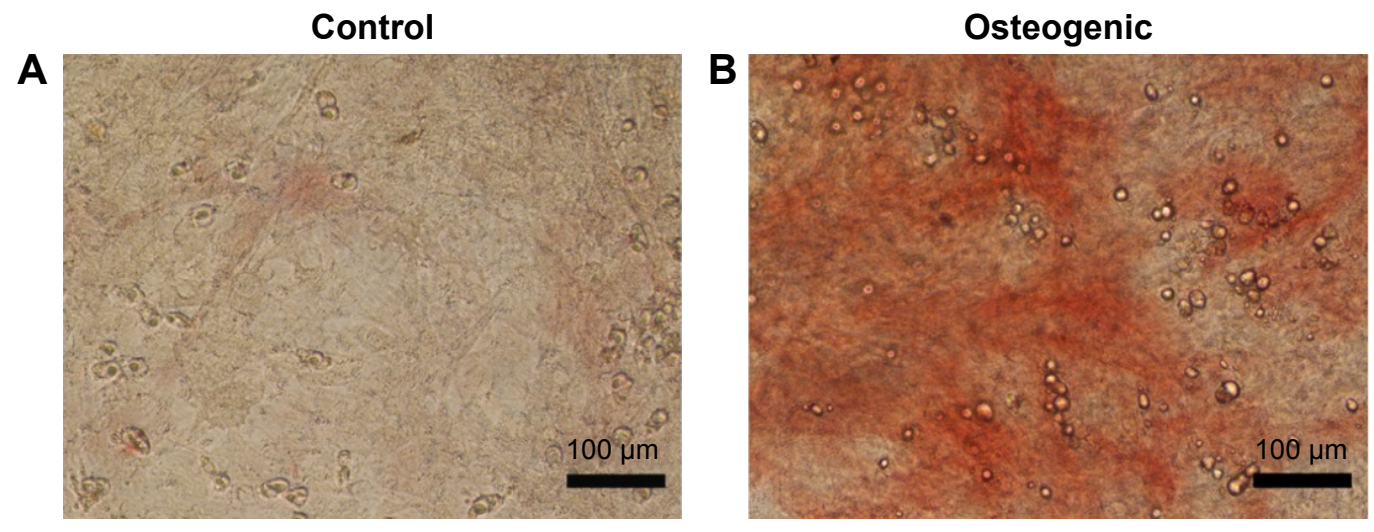

Figure S2 Alizarin Red staining images of BADSCs cultured without (A) or with (B) osteogenic-inducing microenvironment at day I4. Abbreviation: BADSCs, brown adipose-derived stem cells. 


\section{Control}

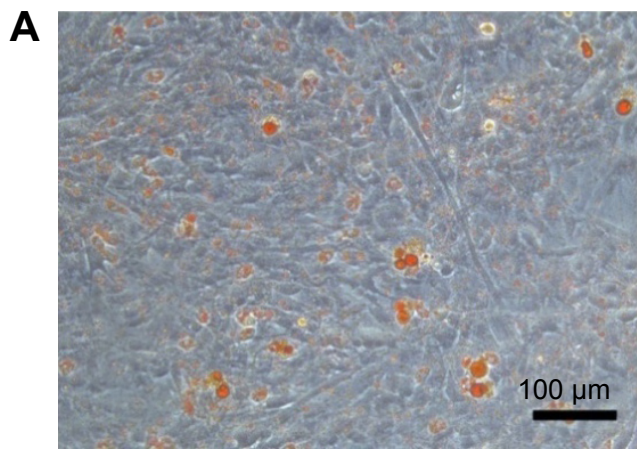

\section{Adipogenic}

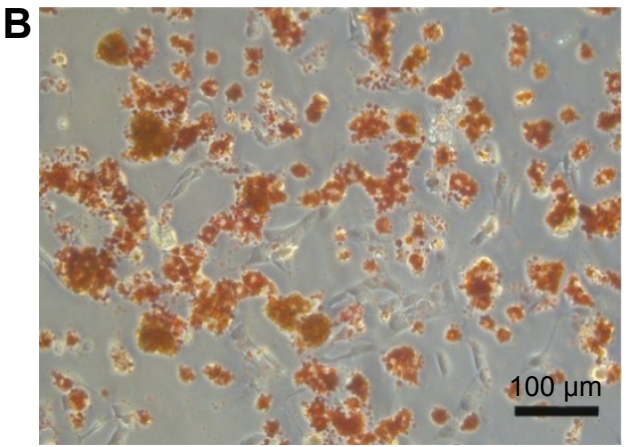

Figure S3 Oil Red O staining images of BADSCs cultured without (A) or with (B) adipogenic-inducing microenvironment at day 7. Abbreviation: BADSCs, brown adipose-derived stem cells.
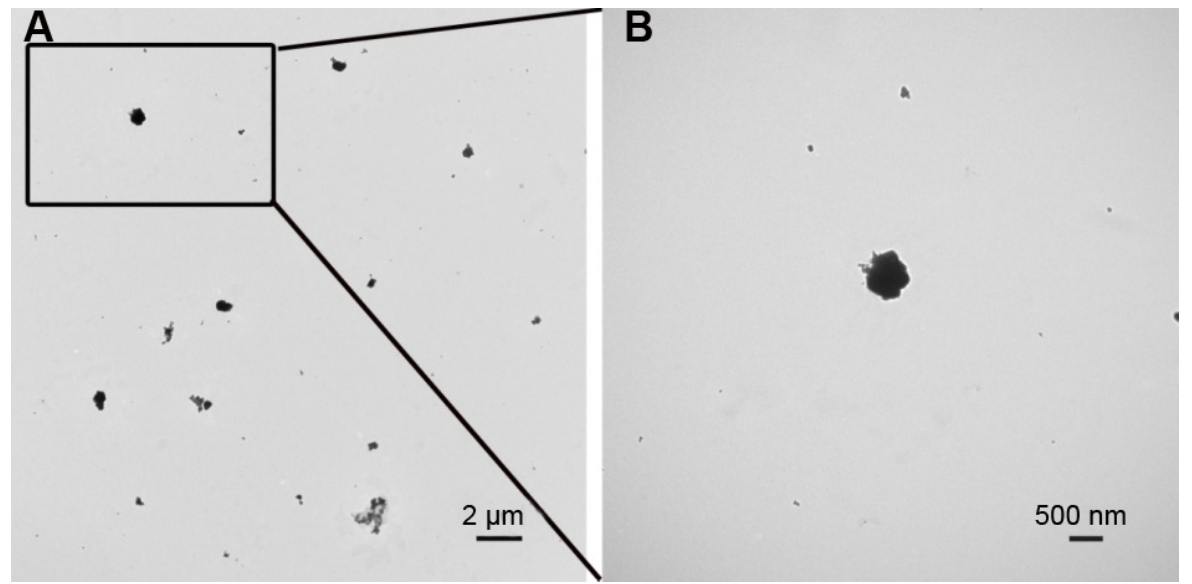

Figure S4 The TEM images of fullerene- $C_{60}$ nanoparticles.

Notes: (A) Morphology image of fullerene- $\mathrm{C}_{60}$. (B) The zoom of selected area in (A).

Abbreviation: TEM, transmission electron microscopy.

osteogenic microenvironment are both positive for Alizarin Red at day 14 , indicating that the BADSCs have been differentiated into osteoblast. And most cells cultured under adipogenic microenvironment are positive for Oil Red $\mathrm{O}$ at day 7 (Figure S3), suggesting that the BADSCs have differentiated into adipocyte.

\section{References}

1. Di Felice V, De Luca A, Colorita ML, et al. Cardiac stem cell research: an elephant in the room? Anat Rec. 2009;292:449-454.

2. Pouly J, Bruneval P, Mandet C, et al. Cardiac stem cells in the real world. J Thorac Cardiovasc Surg. 2008;135:673-678.
International Journal of Nanomedicine

\section{Publish your work in this journal}

The International Journal of Nanomedicine is an international, peerreviewed journal focusing on the application of nanotechnology in diagnostics, therapeutics, and drug delivery systems throughou the biomedical field. This journal is indexed on PubMed Central, MedLine, CAS, SciSearch $\AA$, Current Contents ${ }^{\circledR} /$ Clinical Medicine,

\section{Dovepress}

Journal Citation Reports/Science Edition, EMBase, Scopus and the Elsevier Bibliographic databases. The manuscript management system is completely online and includes a very quick and fair peer-review system, which is all easy to use. Visit http://www.dovepress.com/ testimonials.php to read real quotes from published authors. 